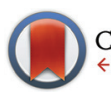

CrossMark \& click for updates

Cite this: Dalton Trans., 2014, 43 15818

Received 30th May 2014, Accepted 14th August 2014

DOI: 10.1039/c4dt01581a

www.rsc.org/dalton

\section{How big is a Cp? Novel cycloheptatrienyl zirconium complexes with tri-, tetra- and pentasubstituted cyclopentadienyl ligands $\uparrow$}

\author{
Heiko Bauer, ${ }^{a}$ Andreas Glöckner, ${ }^{b}$ Alain C. Tagne Kuate, ${ }^{b}$ Sebastian Schäfer, ${ }^{c}$ \\ Yu Sun, ${ }^{a}$ Matthias Freytag, ${ }^{\text {b }}$ Matthias Tamm, ${ }^{* b}$ Marc D. Walter*b and \\ Helmut Sitzmann*a
}

\begin{abstract}
The new bulky cyclopentadienyl anions 1,2,4-tri(cyclopentyl)cyclopentadienide and 2,3-diisopropyl-1,4dimethyl-5-trimethylsilyl-cyclopentadienide were prepared. These and the already known 1,2,4-tri(cyclohexyl)-, 1,2,4-tri(isopropyl)-, 2,3-diisopropyl-1,4-dimethyl-, 1,3,4-triisopropyl-2,5-dimethyl-, pentaphenyl-, and p-butylphenyl-tetraphenyl-cyclopentadienide as well as tert-butylindenide were coordinated to the cycloheptatrienylzirconium fragment [( $\mathrm{CHT}) \mathrm{ZrCl}(\mathrm{tmeda})]$. The nine zirconium complexes of the [(CHT)Zr(Cp)] type were characterized by elemental analysis and NMR spectroscopy. For five of the sandwich complexes $\mathrm{X}$-ray crystal structure determination could be carried out; structures of the four others were obtained by DFT calculations. The data serve as a basis for cone angle measurements of cyclopentadienyl ligands to evaluate the steric demand of these ligands.
\end{abstract}

\section{Introduction}

In the late forties of the last century the parent cyclopentadienyl ligand was seized by freshly reduced iron from cyclopentadiene vapors at $300{ }^{\circ} \mathrm{C}^{1}$ to form a complex later called ferrocene and initiating a rush for cyclopentadienyl complexes of other metals as well. ${ }^{2-4}$ About 20 years later, when titanium tetrachloride was reacted with butane isomers and other olefins at $300{ }^{\circ} \mathrm{C}$ in an autoclave, unexpected pentamethylcyclopentadienyltitanium trichloride ${ }^{5}$ was assembled which stimulated experiments with this prototype of polysubstituted cyclopentadienyl ligands. ${ }^{6}$ Sterically bulky cyclopentadienyl ligands and their metal complexes have been described in review articles. ${ }^{7,8}$ Among more than 2600 experimentally investigated cyclopentadienylzirconium complexes, only about $30 \%$ carry at least one unsubstituted cyclopentadienyl ligand, the

\footnotetext{
${ }^{a}$ Fachbereich Chemie, Technische Universität Kaiserslautern, Erwin-Schroedinger Strasse,67663 Kaiserslautern, Germany.E-mail: sitzmann@chemie.uni-kl.de; Fax: +49 631-205-4676; Tel: +49 631-205-4399

${ }^{b}$ Institut für Anorganische und Analytische Chemie, Technische Universität Braunschweig, Hagenring 30, 38106 Braunschweig, Germany.

E-mail: m.tamm@tu-bs.de; Fax: +49 531-391-5309; Tel: +49 531-391-5387

${ }^{c}$ Institut für Anorganische Chemie, Karlsruher Institut für Technologie, Engesserstr. 15, 76131 Karlsruhe, Germany

$\dagger$ Electronic supplementary information (ESI) available: Details of the electronic structure calculations, X-ray data, the determination of $\Theta$ and $\Omega$, and discussions of NMR spectra of five complexes. CCDC 1012756-1012760. For crystallographic data in CIF or other electronic format see DOI: 10.1039/c4dt01581a
}

remaining $70 \%$ exhibit only substituted cyclopentadienyl ligands. For cyclopentadienyl complexes of other metals this fraction may be lower, but cyclopentadienylzirconium complexes are frequently used as catalysts, whose performance can be modified and even tailored with ring substituents. ${ }^{9}$

As early as 1970 the steric bulk of triorganophosphine ligands was quantified by Tolman using a cone angle approach. ${ }^{10}$ While the number of cyclopentadienyl complexes known in the literature (more than 41700 ) is in the same order of magnitude as the number of complexes with tertiary phosphine ligands (more than 51000 ), ${ }^{11}$ the attention received by one article on the steric bulk of phosphine ligands ${ }^{12}$ by far exceeds the combined impact of a number of review articles on the quantification of the steric bulk of cyclopentadienyl ligands. The work of Möhring and Coville is focused on the polymerization activity of group IV metallocene derivatives. The authors analyzed a large number of olefin polymerization results and concluded that the catalyst activity is dominated to ca. $80 \%$ by the electronic influence of the two cyclopentadienyl, indenyl, or fluorenyl ligands used..$^{13-15}$ The steric bulk of the cyclopentadienyl ligands in titanocene derivatives was concluded to affect both the angular opening between the two Cp planes corresponding to the access of reactants to the metal center and the angular opening in the plane bisecting the two $\mathrm{Cp}$ planes, which limits the angle between the Ti-C(polymer) $\sigma$ bond and the direction of the olefin approach. ${ }^{16}$ Janiak et al. concluded, in contrast, that steric effects dominate the catalytic activity of zirconocene derivatives ${ }^{17,18}$ and find "no influ- 
ence of ... electronic effects ...". ${ }^{18}$ Different methods of substituted cyclopentadienyl bulk quantification have been outlined in the literature, ${ }^{19}$ which was later updated in the literature ${ }^{20}$ where steric bulk measures mostly derived from zirconocene or ferrocene derivatives for 35 cyclopentadienyl ligands with 0-1 substituents and for 8 cyclopentadienyl ligands with two isopropyl or cyclohexyl substituents, two or three $t \mathrm{Bu}$ groups or 2-5 methyl groups have been listed. Another early approach used force field calculations on 24 iron(II) cyclopentadienyl complexes with a fixed Fe-ring centroid distance of $1.73 \AA^{21}$ For most of the bulky cyclopentadienyl ligands with two and more substituents such values are not available. In our research activities bulky alkylcyclopentadienyl ligands play a central role, because they can be used to prevent metal complexes from falling into their preferred energetic sink. For our research a systematic evaluation of steric bulk is therefore quite important.

For this reason, we have embarked on an approach, where an average cone angle derived from crystallographic data quantifies the steric bulk of the substituted cyclopentadienyl ligand and additional information on the bulk of the individual substituents is provided by a substituent cone angle adding numerical information on the third dimension. ${ }^{22}$ The cycloheptatrienyl-zirconium fragment, which turned out to be a very versatile starting compound for an extensive chemistry, ${ }^{23}$ offers good crystallinity and more than one hemisphere of one of the largest transition metals for very bulky cyclopentadienyl ligands. Thus, these CHT-Zr complexes are the materials of choice for the investigation.

\section{Results and discussion}

\section{Synthesis of cyclopentadienyl ligands}

The synthesis of tricyclopentylcyclopentadiene $\mathrm{HCp}^{\text {cpent }}(2-\mathrm{H})$ from the parent cyclopentadiene followed a variation ${ }^{24}$ of the phase-transfer alkylation process ${ }^{25}$ in a system consisting of aqueous potassium hydroxide solution and an organic phase containing cyclopentadiene, cyclopentyl bromide, and cyclopentadiene alkylation products (Scheme 1).

Metalation of the 2- $\mathrm{H}$ mixture of isomers with sodium amide gave $46 \%$ yield of the sodium salt 2 -Na.

For the synthesis of potassium 3,4-diisopropyl-2,5-dimethyl1-trimethylsilylcyclopentadienide (6-K, Scheme 2) sodium 2,3diisopropyl-1,4-dimethylcyclopentadienide ${ }^{26}$ was silylated with chlorotrimethylsilane in tetrahydrofuran to furnish $61 \%$ yield

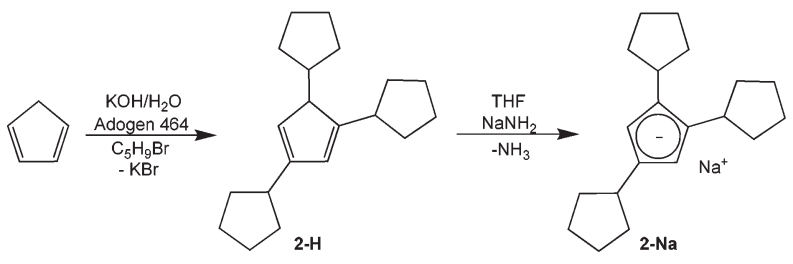

Scheme 1 Synthesis of sodium tri(cyclopentyl)cyclopentadienide $\mathrm{NaCp}{ }^{\text {cpent }}(2-\mathrm{Na})$.

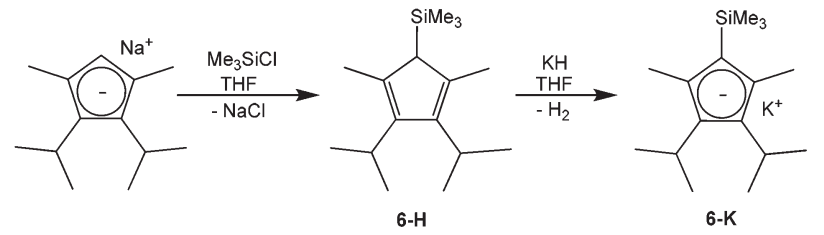

Scheme 2 Synthesis of potassium 3,4-diisopropyl-2,5-dimethyl-1-trimethylsilylcyclopentadienide $\mathrm{K}^{\mathrm{TMS}}(6-\mathrm{K})$.

of the silylated cyclopentadiene tautomers 6- $\mathrm{H}$, which could be metalated with potassium hydride to the potassium salt $6-\mathrm{K}$ in $77 \%$ yield.

Literature citations regarding the preparation of other cyclopentadienides used in this study can be found in the experimental part.

\section{Synthesis and characterization of cycloheptatrienyl zirconium complexes 2-10}

Salt metathesis reaction between the cycloheptatrienyl zirconium chloride $\mathbf{1}$ and the substituted cyclopentadienides or the indenide was performed in THF solution at $-78{ }^{\circ} \mathrm{C}$ (Scheme 3). The changing colour of the reaction mixture turned out to be a very good indicator for the progress of the reaction. Whereas a mixture of the dark blue solution of $\mathbf{1}$ and the brown solution of the cyclopentadienyl salt displays a grey colour, this turns purple after some minutes or hours, depending on the reaction rate.

The synthesis of the cycloheptatrienyl zirconium complex $\left[\left(\mathrm{C}_{7} \mathrm{H}_{7}\right) \mathrm{Zr}\left\{\mathrm{C}_{5} \mathrm{H}_{2}\left(\mathrm{C}_{5} \mathrm{H}_{9}\right)_{3}-1,2,4\right\}\right]$ (2) via a reaction between [(CHT)$\mathrm{ZrCl}($ tmeda)] (1) and 2-Na afforded 53\% yield of purple needles. A discussion of proton and ${ }^{13} \mathrm{C}$ NMR spectra of complex 2 can be found in the ESI. $\dagger$

A crystal structure determination reveals the first structural characterization of the 1,2,4-tricyclopentylcyclopentadienyl ligand in complex 2 (Fig. 1). The three cyclopentyl rings show the expected envelope conformation and are rotated such that the methyne hydrogen atom at the $\alpha$ carbon atom is close to the cyclopentadienyl plane, one of the $\beta$ carbon atoms is above

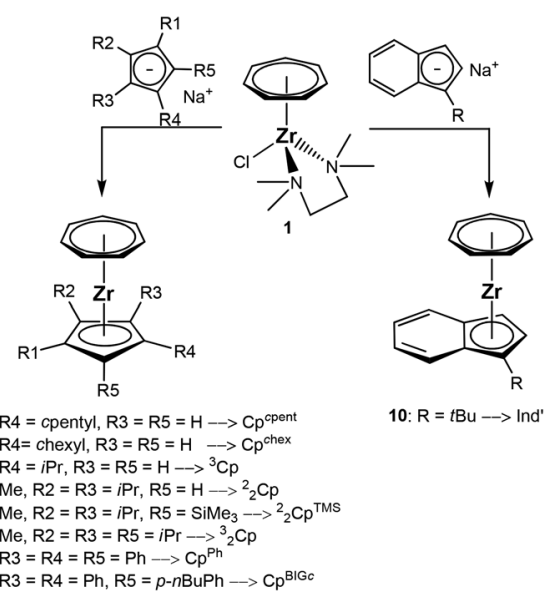

Scheme 3 Synthesis of cycloheptatrienyl zirconium complexes 2-10. 


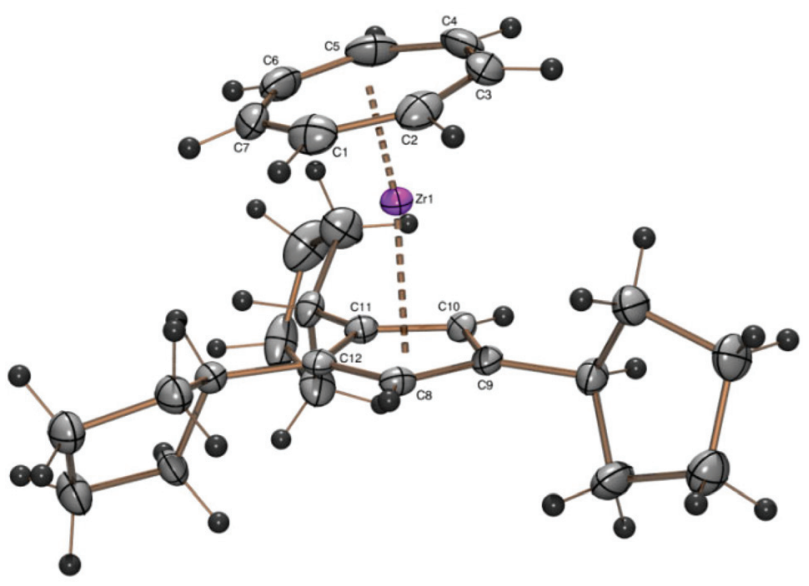

Fig. 1 ORTEP plot of the molecular structure of 2. Atomic displacement parameters have been drawn at $50 \%$ probability. Selected bond length $(\AA)$ and angles $\left({ }^{\circ}\right)$ : $\mathrm{Zr}-\mathrm{C} 1$ 2.327(3), $\mathrm{Zr}-\mathrm{C} 2$ 2.339(3), $\mathrm{Zr}-\mathrm{C} 32$ 2.363(3), $\mathrm{Zr}-\mathrm{C} 4$ 2.348(3), $\mathrm{Zr}-\mathrm{C} 5$ 2.341(4), $\mathrm{Zr}-\mathrm{C} 6 \mathrm{2}$ 2.327(3), $\mathrm{Zr}-\mathrm{C} 7,2.328(4)$, $\mathrm{Zr}-\mathrm{C} 8$ 2.482(3), Zr-C9 2.515(3), Zr-C10 2.491(3), Zr-C11 2.511(2), $\mathrm{Zr}-\mathrm{C} 12$ 2.496(3), $\mathrm{Zr}-\mathrm{Cp}_{\text {cent }} 2.191, \mathrm{Zr}-\mathrm{CHT}_{\text {cent }} 1.673, \mathrm{CHT}_{\text {cent }}-\mathrm{Zr}-\mathrm{Cp}_{\text {cent }}$ 172.03.

and the other below the cyclopentadienyl plane. Both $\beta$ carbon atoms of all three cyclopentyl substituents point towards a $\mathrm{CH}$ group of the cyclopentadienyl ligand, the two vicinal cyclopentyl substituents in 1- and 2-positions are turned away from each other. All three $\mathrm{C}_{5}$ envelopes see the cyclopentadienyl moiety in an exo and the $\alpha$ (methyne) hydrogen atom in an endo position as expected from a steric point of view. The $\mathrm{Zr}$ $\mathrm{CHT}_{\text {cent }}$ distance $(1.673 \AA)$ is much smaller than the $\mathrm{Zr}-\mathrm{Cp}_{\text {cent }}$ distance $(2.191 \AA)$ because of the larger ring diameter of the cycloheptatrienyl ligand and the steric demand of the cyclopentadienyl ring. Due to the arrangement of the cyclopentyl substituents described before, the CHT ligand is tilted towards the two substituents in 1- and 2-positions $\left(\mathrm{CHT}_{\text {cent }}-\mathrm{Zr}-\mathrm{Cp}_{\text {cent }}\right.$ $\left.172.03^{\circ}\right)$.

Other features of the crystallographically determined or theoretically calculated molecular structures of complexes 2-10 are collected in Table 2, details like individual $\mathrm{Zr}-\mathrm{C}$ distances are listed in the figure caption of Fig. 1.

The tricyclohexylcyclopentadienyl derivative $\left[\left(\mathrm{C}_{7} \mathrm{H}_{7}\right) \mathrm{Zr}\right.$ $\left.\left\{\mathrm{C}_{5} \mathrm{H}_{2}\left(\mathrm{C}_{6} \mathrm{H}_{11}\right)_{3}-1,2,4\right\}\right]$ (3) was obtained as purple crystals in $54 \%$ yield from 1 and sodium tricyclohexylcyclopentadienide $(3-\mathrm{Na})^{28}$ by the procedure used also for the synthesis of 2 . A discussion of proton and ${ }^{13} \mathrm{C}$ NMR spectra of complex 3 can be found in the ESI. $\uparrow$ The structure of $\mathbf{3}$ was obtained by DFT calculations (Fig. 2), which arrived at a conformation very similar to that discussed for the crystallographically characterized structure of 2 .

The calculated distances $\left(1.684 \AA\right.$ for $\mathrm{CHT}_{\text {cent }}-\mathrm{Zr}$ and 2.213 $\AA$ for $\mathrm{Cp}_{\text {cent }}-\mathrm{Zr}$ ) are slightly longer than the values for 2 , a tendency, which was found for all calculated structures, irrespective of their steric demand (Table 2). The validity of these calculations had been demonstrated for the tetraisopropylcyclopentadienyl derivative $\left[\left(\mathrm{C}_{7} \mathrm{H}_{7}\right) \mathrm{Zr}\left(\mathrm{C}_{5} \mathrm{H}^{\mathrm{i}} \mathrm{Pr}_{4}\right)\right]$ before. ${ }^{22}$ In this

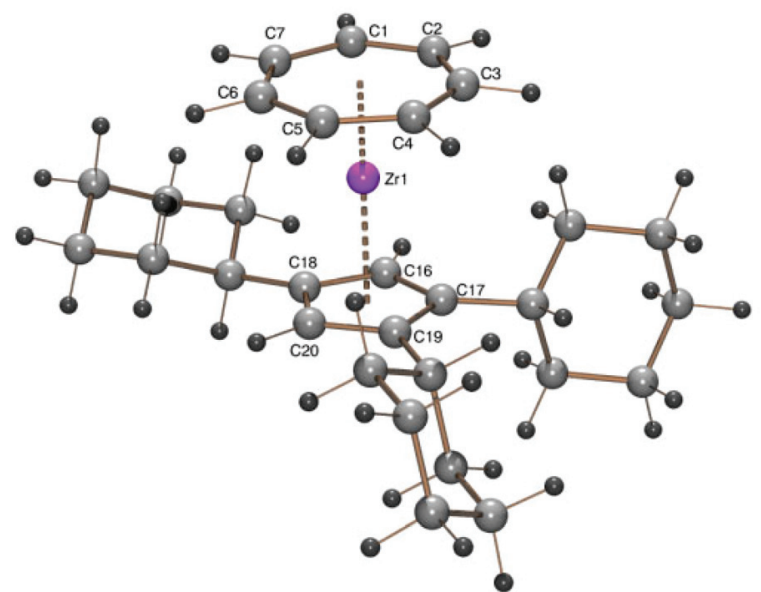

Fig. 2 ORTEP plot of the calculated structure of 3 . Calculated bond length ( $\AA$ ) and angles $\left(^{\circ}\right)$ : $\mathrm{Zr}-\mathrm{C} 1$ 2.352, $\mathrm{Zr}-\mathrm{C} 2$ 2.353, $\mathrm{Zr}-\mathrm{C} 3$ 2.349, $\mathrm{Zr}-\mathrm{C} 4$ 2.347, Zr-C5 2.353, Zr-C6 2.351, Zr-C7 2.353, Zr-C16 2.511, Zr-C17 2.535, Zr-C18 2.523, Zr-C19 2.529, Zr-C20 2.508, Zr-Cp cent $2.213, \mathrm{Zr}-$ $\mathrm{CHT}_{\text {cent }} 1.684, \mathrm{CHT}_{\text {cent }}-\mathrm{Zr}-\mathrm{Cp}_{\text {cent }} 178.06$.

case the largest difference between the experimental and the calculated $\mathrm{Zr}-\mathrm{C}$ distances, for example, was found for $\mathrm{Zr}-\mathrm{C} 4$ (2.346(4) vs. $2.370 \AA$ ). For the other eleven $\mathrm{Zr}-\mathrm{C}$ distances the deviation was found well below $1 \%$.

From sodium 1,2,4-triisopropylcyclopentadienide $\left({ }^{3} \mathrm{Cp}\right)$ and the zirconium starting compound $\mathbf{1}$ the triisopropylcyclopentadienyl derivative $\left[\left(\mathrm{C}_{7} \mathrm{H}_{7}\right) \mathrm{Zr}\left\{\mathrm{C}_{5} \mathrm{H}_{2}\left(\mathrm{i}-\mathrm{C}_{3} \mathrm{H}_{7}\right)_{3}-1,2,4\right\}\right]$ (4) was obtained as purple crystals in $60 \%$ yield. The spectroscopic properties of the 1,2,4-triisopropylcyclopentadienyl ligand have been discussed before. ${ }^{27}$ Since the crystals were found unsuitable for X-ray diffraction, a structure was obtained by DFT calculations (Fig. 3). The calculation shows the expected structure of the complex. The isopropyl substituent in the 4-position is oriented in a way that one methyl carbon atom is close to the ring plane and the methyne proton points towards the zirconium atom to reduce steric strength. Resulting from this orientation, the cycloheptatrienyl ring is tilted towards the

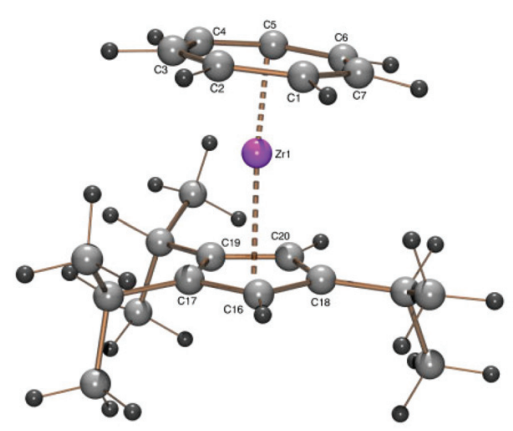

Fig. 3 ORTEP plot of the calculated structure of 4 . Calculated bond length $(\AA \AA)$ and angles $\left(^{\circ}\right)$ : $\mathrm{Zr}-\mathrm{C} 1$ 2.349, $\mathrm{Zr}-\mathrm{C} 2$ 2.360, Zr-C3 2.356, ZrC4 2.346, Zr-C5 2.344, Zr-C6 2.339, Zr-C7 2.342, Zr-C16 2.508, Zr$\mathrm{C} 17$ 2.522, Zr-C18 2.515, Zr-C19 2.524, Zr-C20 2.505, Zr-Cp cent 2.205, $\mathrm{Zr}-\mathrm{CHT}_{\text {cent }} 1.679, \mathrm{CHT}_{\text {cent }}-\mathrm{Zr}-\mathrm{Cp}_{\text {cent }} 174.20$. 
Table 1 Crystallographic data for complexes 2, 5, 6, 8 and 10

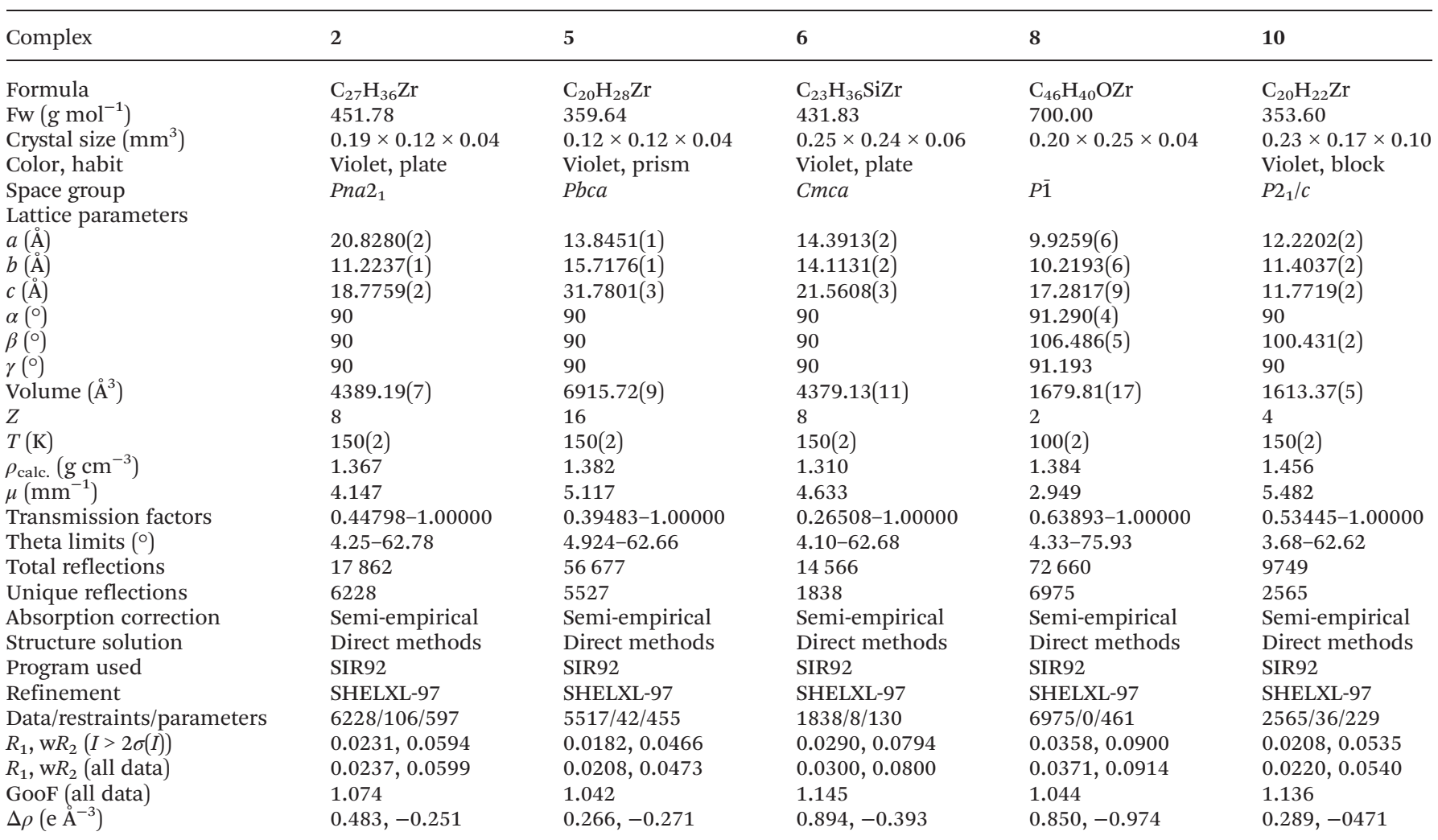

4-position of the five-membered ring $\left(\mathrm{CHT}_{\text {cent }}-\mathrm{Zr}-\mathrm{Cp}_{\text {cent }}\right.$ $\left.174.20^{\circ}\right)$.

Even with the almost insoluble sodium 2,3-diisopropyl-1,4dimethylcyclopentadienide ${ }^{26}\left({ }_{2}^{2} \mathrm{Cp}\right)$ the reaction with the blue solution of 1 proceeded smoothly and afforded the sublimable sandwich complex $\left[\left(\mathrm{C}_{7} \mathrm{H}_{7}\right) \mathrm{Zr}\left\{\mathrm{C}_{5} \mathrm{H}\left(\mathrm{i}-\mathrm{C}_{3} \mathrm{H}_{7}\right)_{2}-2,3-\left(\mathrm{CH}_{3}\right)_{2}-1,4\right\}\right]$ (5) as purple crystals in $76 \%$ yield. ${ }^{1} \mathrm{H}$ and ${ }^{13} \mathrm{C}$ NMR spectra exhibit the signals expected for pairs of symmetry-equivalent methyl and isopropyl substituents (the latter with two diastereotopic methyl positions, $c f$. lit. $^{27}$ ) as well as the $\mathrm{CH}$ signals for both ring ligands. The violet prisms of $\mathbf{5}$ obtained by sublimation at about $120^{\circ} \mathrm{C}$ in a sealed glass tube at $10^{-3}$ mbar gave $\mathrm{X}$-ray diffraction data of excellent quality $\left(\mathrm{w} R_{2}\right.$ value 0.0473 , all data, Table 1) (Fig. 4).

Due to the sterically demanding isopropyl substituents in 2and 3-positions, the cycloheptatrienyl ligand is tilted towards the substitution gap of the cyclopentadienyl ring $\left(167.98^{\circ}\right)$. The $\mathrm{Zr}-\mathrm{CHT}_{\text {cent }}$ distance of $1.677 \AA$ and the $\mathrm{Cp}_{\text {cent }}-\mathrm{Zr}$ distance of $2.192 \AA$ are in the same range as for other complexes of the $[(\mathrm{CHT}) \mathrm{Zr}(\mathrm{Cp})]$ type.

The steric bulk of the ${ }_{2}^{2} \mathrm{Cp}$ ligand can be significantly enlarged by replacement of the only hydrogen atom connected to the five-membered ring by a fifth substituent. The trimethylsilyl derivative $\left[\left(\mathrm{C}_{7} \mathrm{H}_{7}\right) \mathrm{Zr}\left\{\mathrm{C}_{5}\left(\mathrm{SiMe}_{3}\right)\left(\mathrm{i}-\mathrm{C}_{3} \mathrm{H}_{7}\right)_{2}-3,4-\left(\mathrm{CH}_{3}\right)_{2}-2,5\right\}\right]$ (6) could be obtained in $39 \%$ yield from the corresponding potassium 3,4-diisopropyl-2,5-dimethyl-1-trimethylsilylcyclopentadienide $\left(\mathrm{K}_{2}^{2} \mathrm{Cp}^{\mathrm{TMS}}\right)$ and the zirconium starting compound $\mathbf{1}$.

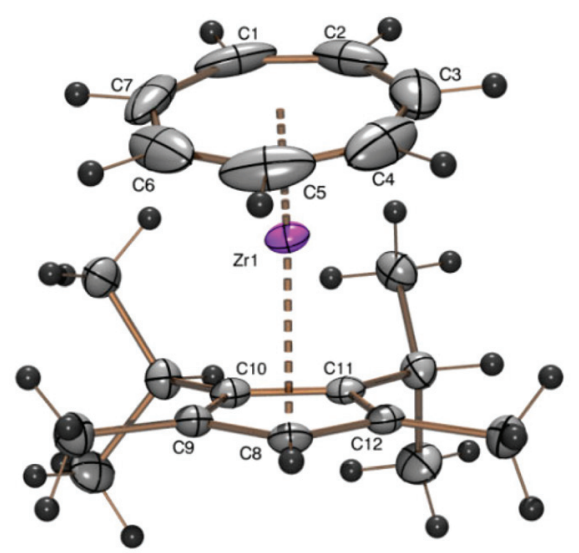

Fig. 4 ORTEP plot of the molecular structure of $\mathbf{5}$. Atomic displacement parameters have been drawn at $50 \%$ probability. Selected bond length ( $(\AA)$ and angles $\left({ }^{\circ}\right)$ : $\mathrm{Zr}-\mathrm{C} 1$ 2.349(2), $\mathrm{Zr}-\mathrm{C} 2$ 2.352(2), $\mathrm{Zr}-\mathrm{C} 32.345$ (2), Zr-C4 2.321(2), Zr-C5 2.310(2), Zr-C6 2.310(2), Zr-C7 2.325(2), ZrC8 2.4714(16), Zr-C9 2.4928(17), Zr-C10 2.2.5358(16), Zr-C11 2.5164 (16), $\mathrm{Zr}-\mathrm{C} 12$ 2.4998(16), $\mathrm{Zr}-\mathrm{Cp}_{\text {cent }} 2.192, \mathrm{Zr}-\mathrm{CHT}_{\text {cent }} 1.677, \mathrm{CHT}_{\text {cent }}{ }^{-}$ $\mathrm{Zr}-\mathrm{Cp}_{\text {cent }} 167.98$.

A discussion of proton and ${ }^{13} \mathrm{C}$ NMR spectra of complex 6 can be found in the ESI. $\dagger$

The crystal structure of the purple orthorhombic blocks obtained by sublimation of 6 in a sealed glass tube under vacuum at $120^{\circ} \mathrm{C}$ shows the protruding silyl group (ring $\mathrm{C}-\mathrm{Si}$ 
Table 2 Comparison of selected structural parameters for complexes 2, 5, 6, 8 and 10 (distances in $\AA$, angles in $\left.{ }^{\circ}\right)^{a}$

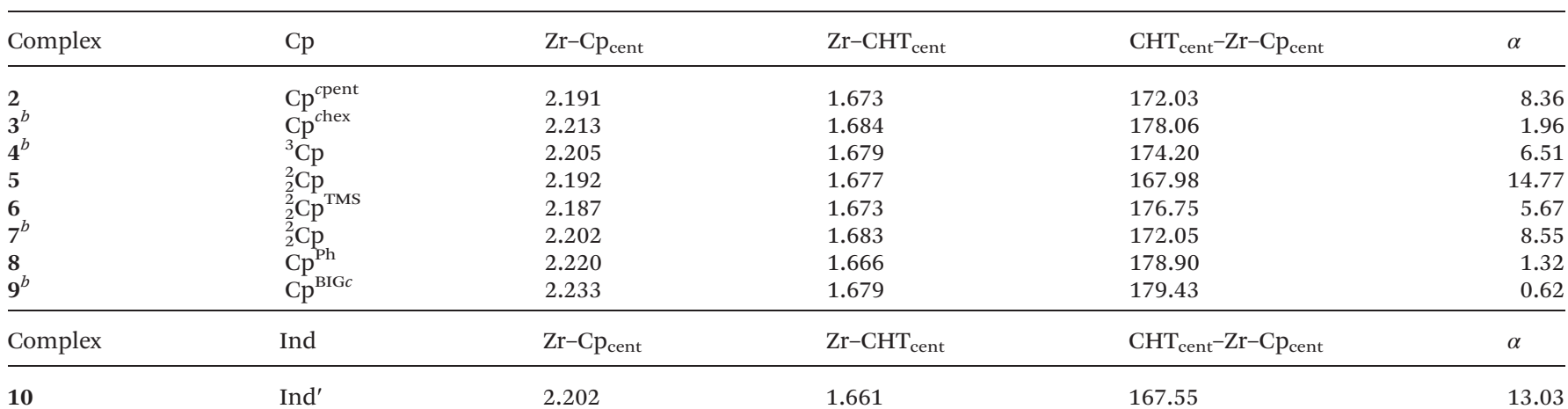

${ }^{a} \mathrm{CHT}=$ cycloheptatrienyl, $\alpha=$ the angle between the two ligand planes. ${ }^{b}$ Data are based on the calculated structure.

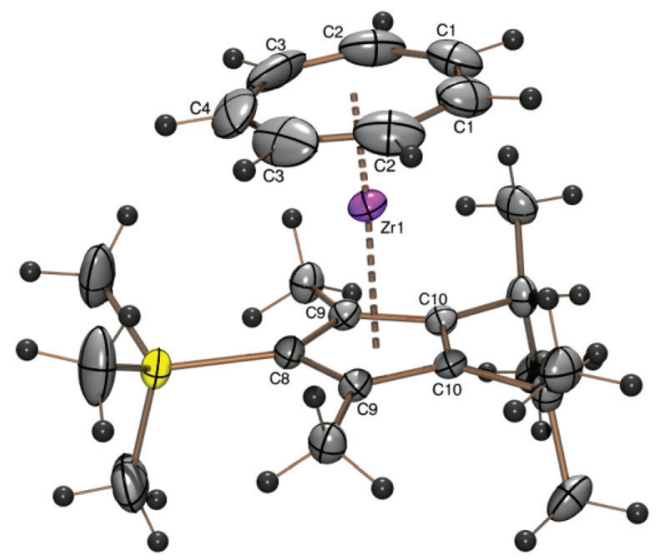

Fig. 5 ORTEP plot of the molecular structure of 6 . Atomic displacement parameters have been drawn at $50 \%$ probability. Selected bond length (Å) and angles ( ${ }^{\circ}$ : $\mathrm{Zr}-\mathrm{C} 12.356(3), \mathrm{Zr}-\mathrm{C} 222.345(3), \mathrm{Zr}-\mathrm{C} 32.322(3)$, $\mathrm{Zr}-\mathrm{C} 4$ 2.308(4), Zr-C8 2.488(3), Zr-C9 2.502(2), Zr-C10 2.5121(19), $\mathrm{Zr}-\mathrm{Cp}_{\text {cent }} 2.187, \mathrm{Zr}-\mathrm{CHT}_{\text {cent }} 1.673, \mathrm{CHT}_{\text {cent }}-\mathrm{Zr}-\mathrm{Cp}_{\text {cent }} 176.75$.

bond length $1.883 \AA$, $\mathrm{Si}-\mathrm{CH}_{3}$ 1.852(5) and 1.860(3) $\AA$ ) and the almost parallel orientation of the ring ligands (Tables 1 and 2 and Fig. 5). The trimethylsilyl substituent is bent $3.78^{\circ}$ out of the five-membered ring plane such as to reduce steric hindrance.

Equipped with a third isopropyl group, the 3,5-dimethyl1,2,4-triisopropylcyclopentadienyl $\left({ }_{2}^{3} \mathrm{Cp}\right)$ ligand could also be introduced using 1 and sodium 3,5-dimethyl-1,2,4-triisopropylcyclopentadienide $(7-\mathrm{Na})^{28}$ to form the sandwich complex $\left[\left(\mathrm{C}_{7} \mathrm{H}_{7}\right) \mathrm{Zr}\left\{\mathrm{C}_{5}\left(\mathrm{i}-\mathrm{C}_{3} \mathrm{H}_{7}\right)_{3}-1,2,4-\left(\mathrm{CH}_{3}\right)_{2}\right\}\right]$ (7) as a purple oil, which could not be crystallized, but analyzed quite well (Experimental part). A discussion of proton and ${ }^{13} \mathrm{C}$ NMR spectra of complex 6 can be found in the ESI. $\dagger$ A structure model had to be calculated by DFT methods (Fig. 6 and Table 2) which shows a slightly bent sandwich structure with an interplanar angle of $8.6^{\circ}$.

The reaction of sodium pentaphenylcyclopentadienide with 1 was successful and afforded the sandwich complex $\left[\left(\mathrm{C}_{7} \mathrm{H}_{7}\right)_{-}\right.$ $\left.\mathrm{Zr}\left(\mathrm{C}_{5} \mathrm{Ph}_{5}\right)\right](8)$ as a purple solid, which is insoluble in hexane or toluene, sparingly soluble in tetrahydrofuran and moder-

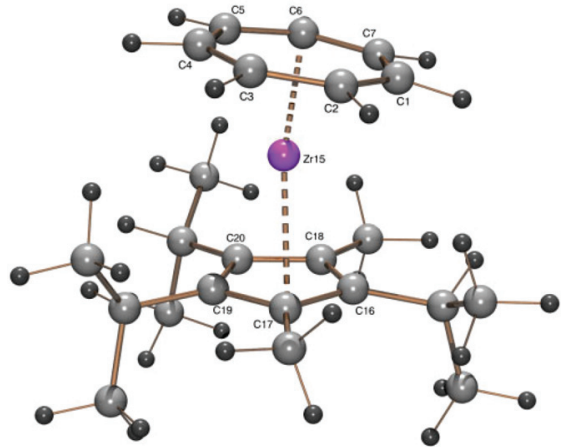

Fig. 6 ORTEP plot of the calculated structure of 7. Calculated bond length $(\AA)$ and angles $\left({ }^{\circ}\right)$ : $\mathrm{Zr}-\mathrm{C} 1$ 2.340, $\mathrm{Zr}-\mathrm{C} 2$ 2.349, $\mathrm{Zr}-\mathrm{C} 3$ 2.359, ZrC4 2.366, Zr-C5 2.358, Zr-C6 2.346, Zr-C7 2.338, Zr-C16 2.518, ZrC17 2.521, Zr-C18 2.515, Zr-C19 2.517, Zr-C20 2.506, Zr-Cp cent 2.202, $\mathrm{Zr}-\mathrm{CHT}_{\text {cent }} 1.683, \mathrm{CHT}_{\text {cent }}-\mathrm{Zr}-\mathrm{Cp}_{\text {cent }} 172.05$.

ately soluble in dichloromethane. $\mathbf{8}$ could be crystallized from saturated solutions in tetrahydrofuran by slow evaporation at ambient temperature. This result is interesting because the corresponding pentaisopropylcyclopentadienyl complex could not be obtained with lithium pentaisopropylcyclopentadienide. $^{22}$ Another attempt at the synthesis of $\left[\left(\mathrm{C}_{7} \mathrm{H}_{7}\right) \mathrm{Zr}-\right.$ $\left.\left(\mathrm{C}_{5}\left(\mathrm{i}-\mathrm{C}_{3} \mathrm{H}_{7}\right)_{5}\right)\right]$ using potassium pentaisopropylcyclopentadienide was also unsuccessful. Thus, it can be supposed that the larger cone angle of the pentaisopropylcyclopentadienide in comparison with the pentaphenylcyclopentadienide is responsible for the failure of $\mathbf{1}$ to react, not the reactivity of the alkali cation (Fig. 7).

Through slow evaporation of a saturated THF solution of $\mathbf{8}$, crystals suitable for X-ray diffraction could be obtained.

During preparation and handling of pentaphenylcyclopentadiene $(8-\mathrm{H})^{29}$ single crystals of this starting compound suitable for X-ray diffraction were obtained. The data for crystal structure determination were measured at room temperature and solved in $P 2_{1} / n$ with two independent molecules in the unit cell. In the literature ${ }^{29}$ there exists another structure of 1,2,3,4,5-pentaphenylcyclopentadiene with one independent molecule in a cell with almost the same cell constants $b=$ 6.267(1) $\AA, c=24.517(8) \AA, \beta=93.49(2)^{\circ}$ as the structure deter- 

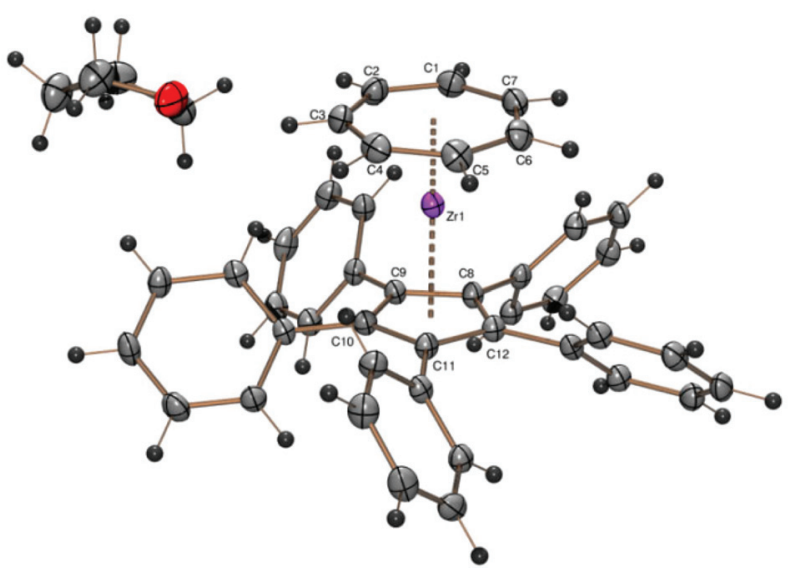

Fig. 7 ORTEP plot of the molecular structure of $\mathbf{8}$. Atomic displacement parameters have been drawn at $50 \%$ probability. Selected bond length ( $(\AA)$ and angles $\left({ }^{\circ}\right): \mathrm{Zr}-\mathrm{C} 12.339(2), \mathrm{Zr}-\mathrm{C} 2$ 2.333(2), $\mathrm{Zr}-\mathrm{C} 32.338$ (2), Zr-C4 2.342(2), Zr-C5 2.335(2), Zr-C6 2.334(2), Zr-C7 2.339(2), ZrC8 2.534(2), Zr-C9 2.536(2), Zr-C10 2.526(2), Zr-C11 2.528(2), Zr-C12 2.536(2), $\mathrm{Zr}-\mathrm{Cp}_{\text {cent }} 2.220, \mathrm{Zr}-\mathrm{CHT}_{\text {cent }} 1.666, \mathrm{CHT}_{\text {cent }}-\mathrm{Zr}-\mathrm{Cp}_{\text {cent }} 178.9$.

mined in our laboratory with $a=24.3208(8) \AA, b=6.2097(2) \AA$, $\beta=93.649(3)^{\circ}$, except for $c$ (previously 15.954(4) $\AA$, we found $c=31.4383(10) \AA$ ). Careful analyses of both structures provided no indication of any obvious mistake in the structure determination. A possible explanation would be a slow phase transformation without any destructive effects on the crystal upon cooling from room temperature to $-173{ }^{\circ} \mathrm{C}$.

The introduction of a butyl chain in the para position of one of the phenyl rings of the pentaphenylcyclopentadienyl ligand was accomplished as described for the tert-butyl derivative. ${ }^{30}$ Indeed the purple complex $\left[\left(\mathrm{C}_{7} \mathrm{H}_{7}\right) \mathrm{Zr}_{2}\left\{\mathrm{C}_{5} \mathrm{Ph}_{4^{-}}\right.\right.$ $\left.\left.\left(\mathrm{C}_{6} \mathrm{H}_{4} n \mathrm{Bu}-4\right)\right\}\right]$ (9) obtained from the potassium salt of 4-butylphenyl-tetraphenylcyclopentadiene and $\mathbf{1}$ displays better solubility and could be extracted with toluene from the product mixture. After the toluene solution was taken to dryness, the purple residue could be washed with pentane because complex $\mathbf{9}$ is almost insoluble in pentane. Crystallization of $\mathbf{9}$ was not successful from saturated toluene solutions at low temperatures. The product could only be obtained as a fine, purple powder. Thus, a crystal structure of $\mathbf{9}$ could not be obtained and the structure had to be calculated with DFT methods. This calculation reveals a $\mathrm{Zr}-\mathrm{CHT}_{\text {cent }}$ distance of $1.679 \AA$ and a $\mathrm{Zr}-$ $\mathrm{Cp}_{\text {cent }}$ distance of $2.233 \AA$ which are both slightly larger than the corresponding values for the pentaphenyl derivative $\mathbf{8}$. Since one para- $n \mathrm{Bu}$ substituent is not expected to enhance the steric demand of the pentaphenylcyclopentadienyl ligand, the higher values for the centroid-Zr distances might result from the calculation method, as mentioned before (Fig. 8).

While the cycloheptatrienylzirconium complex of the 1,3di(tert-butyl)indenyl ligand as well as of the unsubstituted indenyl ligand have been investigated previously, ${ }^{22}$ the corresponding mono(tert-butyl) derivative has been prepared from 1 and sodium 1-tert-butylindenide and could be crystallized as purple needles from pentane in $47 \%$ yield. A discussion of proton spectra of complex $\mathbf{1 0}$ can be found in the ESI. $\dagger$ The

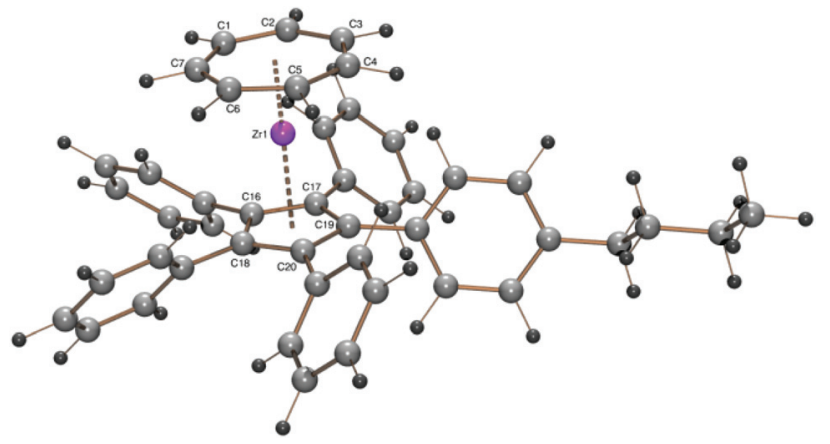

Fig. 8 ORTEP plot of the calculated structure of 9. Calculated bond length (Å) and angles $\left(^{\circ}\right): \mathrm{Zr}-\mathrm{C} 1$ 2.345, $\mathrm{Zr}-\mathrm{C} 2$ 2.351, $\mathrm{Zr}-\mathrm{C} 32.348, \mathrm{Zr}-\mathrm{C} 4$ 2.346, Zr-C5 2.349, Zr-C6 2.347, Zr-C7 2.342, Zr-C16 2.541, Zr-C17 2.542, Zr-C18 2.544, Zr-C19 2.542, Zr-C20 2.541, Zr-Cp cent $2.233, \mathrm{Zr}-$ $\mathrm{CHT}_{\text {cent }} 1.679, \mathrm{CHT}_{\text {cent }}-\mathrm{Zr}-\mathrm{Cp}_{\text {cent }} 179.43$.

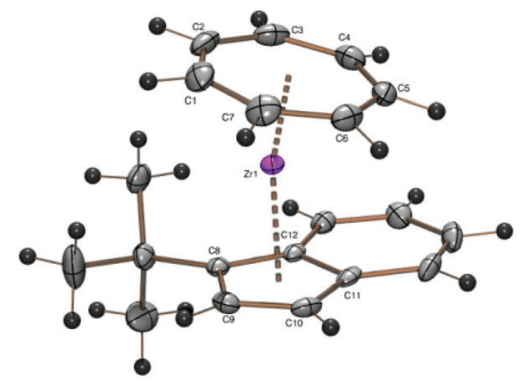

Fig. 9 ORTEP plot of the molecular structure of 10. Atomic displacement parameters have been drawn at $50 \%$ probability. Selected bond length ( $(\AA)$ and angles ( $\left.{ }^{\circ}\right)$ : $\mathrm{Zr}-\mathrm{C} 12$ 2.345(2), $\mathrm{Zr}-\mathrm{C} 2$ 2.354(2), $\mathrm{Zr}-\mathrm{C} 32.349$ (2), Zr-C4 2.319(2), Zr-C5 2.312(2), Zr-C6 2.319(2), Zr-C7 2.334(2), ZrC8 2.507(2), Zr-C9 2.492(2), Zr-C10 2.494, Zr-C11 2.5335(19), Zr-C12 2.544(2), $\mathrm{Zr}-\mathrm{Cp}_{\text {cent }} 2.202, \mathrm{Zr}-\mathrm{CHT}_{\text {cent }} 1.661, \mathrm{CHT}_{\text {cent }}-\mathrm{Zr}-\mathrm{Cp}_{\text {cent }} 167.55$.

chiral molecules crystallize as a racemate in the space group $P 2_{1} / c$, where the enantiomers are symmetry-related by a crystallographic inversion center (Fig. 9).

As expected, the CHT ligand is tilted towards the unsubstituted side of the indenyl ligand $\left(\mathrm{CHT}_{\text {cent }}-\mathrm{Zr}-\mathrm{Cp}_{\text {cent }} 167.55^{\circ}\right)$.

\section{Cone angle measurement}

From crystallographically determined and theoretically calculated structural data, for each complex two cone angles were derived as outlined in an earlier publication. ${ }^{22}$ The angle $\Theta$ is the cone angle of the cyclopentadienyl ligand with the zirconium atom as the apex and the center of the outermost hydrogen of the substituents (with the maximum cone angle $\theta_{\mathrm{i}}$ ) as the limit (Scheme 4, top). The second angle $\Omega$ is defined as the cone angle of the substituents of the $\mathrm{Cp}$ ligand and thus the steric demand of the ligand in the $z$-dimension (Scheme 4, bottom).

The cone angles $\Theta$ and $\Omega$ of the complexes 2-10 reported in this manuscript as well as those reported earlier ${ }^{22}$ are listed in Table 3. In comparison with the triisopropylcyclopentadienyl ligand $\left({ }^{3} \mathrm{Cp}\right)$ the tricyclopentylcyclopentadienyl ligand occupies 

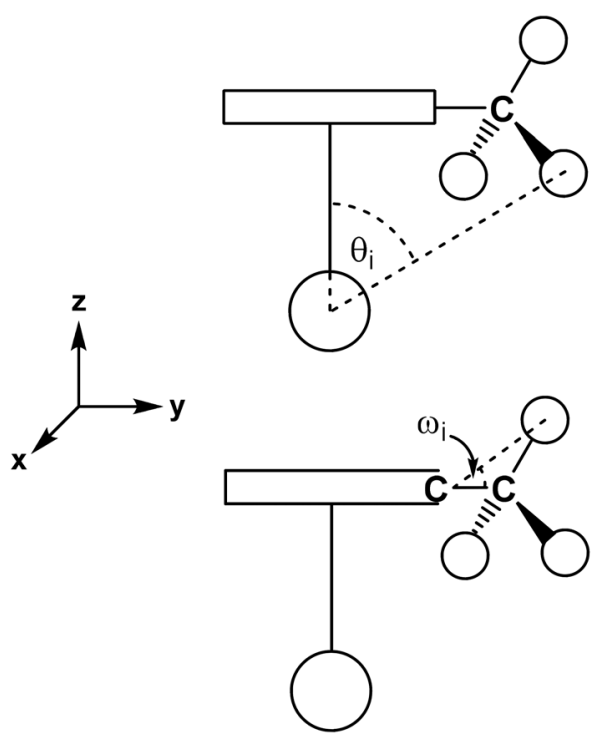

Scheme 4 Measurement of the angles $\theta_{\mathrm{i}}$ and $\omega_{\mathrm{i}}$ leading to $\Theta$ (top) and $\Omega$ (bottom). The large sphere represents the metal and the small spheres represent the methyl hydrogens. The relevant group is not necessarily directly bonded to the ring, nor does it necessarily lie in the ring plane. For each substituent the outermost methyl hydrogen, corresponding to the largest $\theta_{\mathrm{i}}$ value, is chosen.

Table 3 Measured cone angles ( ${ }^{\circ}$ )

\begin{tabular}{|c|c|c|c|}
\hline Complex & $\mathrm{Cp}$ & $\Theta$ & $\Omega^{a}$ \\
\hline$c$ & $\mathrm{C}_{5} \mathrm{H}_{5}$ & 88.2 & 0 \\
\hline$c$ & $\mathrm{C}_{5} \mathrm{H}_{4} \mathrm{CH}_{3}$ & 95.1 & 49.0 \\
\hline c & $\mathrm{C}_{5} \mathrm{H}_{4} \mathrm{Si}\left(\mathrm{CH}_{3}\right)_{3}$ & 104.3 & 95.6 \\
\hline$c$ & $\mathrm{C}_{5} \mathrm{H}_{4}$ (allyl) & 106.0 & 68.6 \\
\hline$c$ & $\mathrm{Cp}^{\prime \prime}$ & 116.2 & 100.7 \\
\hline 2 & $\mathrm{Cp}^{c \text { pent }}$ & 131.7 & 86.1 \\
\hline $3^{d}$ & $\mathrm{Cp}^{c h e x}$ & 134.8 & 89.0 \\
\hline $4^{d}$ & ${ }^{3} \mathrm{Cp}$ & 132.6 & 89.1 \\
\hline c & $\mathrm{Cp}^{\prime \prime \prime}$ & 132.0 & 99.8 \\
\hline $5^{b}$ & ${ }_{2}^{2} \mathrm{Cp}$ & $134.5 / 134.9$ & $69.2 / 69.3$ \\
\hline c & ${ }^{4} \mathrm{Cp}$ & 146.4 & 85.9 \\
\hline$c$ & $\mathrm{Cp}^{*}$ & 122.4 & 51.2 \\
\hline 6 & ${ }_{2}^{2} \mathrm{Cp}^{\mathrm{TMS}}$ & 150.4 & 75.0 \\
\hline $7^{d}$ & ${ }_{2}^{2} \mathrm{Cp}$ & 150.2 & 75.9 \\
\hline 8 & $\mathrm{Cp}^{\mathrm{Ph}}$ & 157.4 & 98.9 \\
\hline $\mathbf{9}^{d}$ & $\mathrm{Cp}^{\mathrm{BIG} c}$ & 163.8 & 104.7 \\
\hline$c, d$ & ${ }^{5} \mathrm{Cp}$ & 167.4 & 88.6 \\
\hline Complex & Indenyl & $\Theta$ & $\Omega$ \\
\hline$c$ & $\mathrm{C}_{9} \mathrm{H}_{7}$ & 102.6 & 0 \\
\hline 10 & Ind' & 119.0 & 101.0 \\
\hline$b, c$ & Ind" & $130.7 / 131.8$ & $101.3 / 100.2$ \\
\hline$b, c$ & Ind $^{\text {chex }}$ & $131.0 / 131.7$ & $84.9 / 84.2$ \\
\hline
\end{tabular}

${ }^{a}$ Calculated for a given substituent by measuring the maximum cone angle of each group in the $\alpha$-C of the substituent with the ipso-C atom as the apex, the averaged. In the case of ${ }^{\mathrm{i}} \mathrm{Pr}$ and $c$ hexyl the $\mathrm{C}-\mathrm{H}$ proton was included in the calculation. ${ }^{b}$ Two independent molecules in the asymmetric unit. ${ }^{c}$ See ref. 22 for details. ${ }^{d}$ Data are based on the calculated structure.

an almost identical, but slightly smaller cone angle $\Theta$ of $131.7^{\circ}$ vs. $132.6^{\circ}$. This tendency is more pronounced, when the cone angles of one isopropyl group $\Omega\left(89.1^{\circ}\right)$ and the cyclopentyl group $\left(86.1^{\circ}\right)$ at the cyclopentadienyl ligand are compared. The reason for the slim appearance of the cyclopentyl group is ring strain visible in the smaller $\mathrm{C} \beta-\mathrm{C} \alpha-\mathrm{C} \beta$ angles of the cyclopentyl substituent (typically between $101.5^{\circ}$ and $102.5^{\circ}$ in complex 2) compared to the same angle for the isopropyl substituents of complexes 5 and 6 (between $110.5^{\circ}$ and $111.5^{\circ}$ ). The cone angle $\Theta$ of the tricyclohexylcyclopentadienyl ligand $\left(134.8^{\circ}\right)$ is larger than that of the tricyclopentylcyclopentadienyl ligand $\left(131.7^{\circ}\right)$ and even slightly larger than that of the triisopropylcyclopentadienyl ligand $\left(132.6^{\circ}\right)$. For the ${ }_{2}^{2} \mathrm{Cp}$ ligand, the cone angle $\Theta$ is comparable even to $\mathrm{Cp}^{\text {chex }}$ (Table 3), but the ring tilt in $\mathbf{5}$ is larger than that in the tris(secondary alkyl)cyclopentadienyl complexes 2-4 (Table 2) because the steric bulk of the ${ }_{2}^{2} \mathrm{Cp}$ ligand is concentrated on one edge of the five-membered ring and rather small on the other side of the ring.

The calculated cone angle $\Theta$ of the ${ }_{2}^{3} \mathrm{Cp}$ ligand $\left(150.2^{\circ}\right)$ is practically identical to that of ${ }_{2}^{2} \mathrm{Cp}^{\mathrm{TMS}}\left(150.3^{\circ}\right)$.

The cone angle $\Theta$ of $167.4^{\circ}$ for the pentaisopropylcyclopentadienyl ligand is significantly larger than the $157.4^{\circ}$ angle for the pentaphenylcyclopentadienide. This could be an explanation for the failure of $\mathbf{1}$ to react; another alkali cation does not make a difference.

The calculated cone angle $\Theta\left(163.8^{\circ}\right)$ of the monobutyl derivative of pentaphenylcyclopentadienide $\left(\mathrm{Cp}^{\mathrm{Ph}}\right)$ is significantly larger than the value found for the pentaphenyl derivative $8\left(157.4^{\circ}\right)$, which is due to the conformation of the ligand and varies with the rotational orientation of the phenyl ring planes relative to the cyclopentadienyl plane. This cone angle should be viewed with caution. There is no obvious reason why one butyl group in the para position should significantly increase the steric bulk the pentaphenylcyclopentadienyl ligand presents to the central atom. The cone angle $\Theta$ of the 1-tert-butylindenyl ligand was determined to be $119^{\circ}$ and is in the expected range between indenyl $\left(102.6^{\circ}\right)$ and 1,3-di(tertbutyl)indenyl ( $c a .131^{\circ}$, see Table 3).

Comparison of the values for the cyclopentadienyl ligands listed in the table above results in the following order of bulk:

$\mathrm{C}_{5} \mathrm{H}_{5}<\mathrm{C}_{5} \mathrm{H}_{4} \mathrm{CH}_{3}<\mathrm{C}_{9} \mathrm{H}_{7} \approx \mathrm{C}_{5} \mathrm{H}_{4} \mathrm{Si}\left(\mathrm{CH}_{3}\right)_{3} \approx \mathrm{C}_{5} \mathrm{H}_{4}($ allyl $)<$ $\mathrm{Cp}^{\prime \prime}<\mathrm{Ind}^{\prime}<\mathrm{C}_{5}\left(\mathrm{CH}_{3}\right)_{5}<{ }_{2}^{2} \mathrm{Cp}<\mathrm{Cp}^{\text {cpent }} \approx{ }^{3} \mathrm{Cp} \approx \mathrm{Cp}^{\text {chex }}<{ }_{2}^{2} \mathrm{Cp}^{\mathrm{TMS}}$ $<{ }_{2}^{3} \mathrm{Cp}<\mathrm{Ind}^{\prime \prime} \approx \mathrm{Ind}^{\text {chex }} \approx \mathrm{Cp}^{\prime \prime \prime}<\mathrm{Cp}^{\mathrm{Ph}}<{ }^{4} \mathrm{Cp}<\mathrm{Cp}^{\mathrm{BIG} c}<{ }^{5} \mathrm{Cp}$

If the cone angle of the cycloheptatrienyl ligand is calculated according to the equation $\Theta=\left(\Theta_{1}+\Theta_{2}+\Theta_{3}+\Theta_{4}+\Theta_{5}+\right.$ $\left.\Theta_{6}+\Theta_{7}\right) \times 2 / 7$, values of $117-118^{\circ}$ are obtained, which place the steric demand of the CHT ligand between those of 1,3-di(tert-butyl)cyclopentadienyl and 1-tert-butylindenyl ligands.

\section{Conclusion}

The cycloheptatrienylzirconium fragment accommodates cyclopentadienyl ligands as bulky as tetraisopropylcyclopentadienyl or pentaarylcyclopentadienyl without steric interactions with the cycloheptatrienyl ligand. Up to now sixteen derivatives of the $[(\mathrm{CHT}) \operatorname{Zr}(\mathrm{Cp})]$ type with different cyclopentadienyl or indenyl ligands coordinated to the cycloheptatrienylzirconium 
fragment crystal structures have been obtained and used for data compilation.

The cone angle $\Theta$ of the substituted cyclopentadienyl ligand alone in some cases leads to unrealistic conclusions. Tetraisopropylcyclopentadienide, for instance, is bulkier than triisopropyl-dimethylcyclopentadienide, but the cone angles are reverted. Similarly, diisopropyl-dimethylcyclopentadienide, triisopropylcyclopentadienide, and tri(tert-butyl)cyclopentadienide exhibit very similar cone angles $\Theta$ for the ligand, but the cone angles $\Omega$ of the substituents are different. It is therefore necessary to take both values into account when comparing different cyclopentadienyl derivatives. The cone angles found experimentally for the pentaphenylcyclopentadienyl ligand and by DFT calculations for its close relative $\mathrm{Cp}^{\mathrm{BIG}}$ with just one $n$-butyl group added in the para position of one phenyl ring differing by $\mathrm{ca} .6^{\circ}$ are due to different torsion angles of the substituents. This discrepancy may arise from crystal packing forces or may be sensitive to the basis sets used for the calculations.

\section{Experimental section}

\section{General}

All preparations and spectroscopic manipulations of air and moisture sensitive compounds were carried out under an atmosphere of nitrogen or argon, using Schlenk line techniques and a glove box (MBraun company, Garching) filled with argon. Solvents were rigorously dried and deoxygenated by distillation under nitrogen with molten potassium (tetrahydrofuran) or sodium/potassium alloy (pentane, benzene-d6) and distilled prior to use. Bruker Avance 400 and Avance 600 spectrometers were used to obtain NMR spectra which were referenced to the residual solvent signal $\left(\mathrm{C}_{6} \mathrm{D}_{6}: 7.16 \mathrm{ppm}\right)$. The chemical shifts $\delta$ are given in ppm and the coupling constants $J$ are given in Hz. Elemental analyses were carried out in the analytical laboratory of the chemical department of the TU Kaiserslautern, using a Vario Micro Tube of Elementar Analysentechnik/Hanau. Crystal structures were obtained by XRD measurements on an Oxford Diffraction Gemini Ultra diffractometer.

The sodium salts $\mathrm{NaCp}^{\text {chex }},{ }^{32} \mathrm{Na}^{3} \mathrm{Cp},{ }^{27} \mathrm{Na}_{2}^{2} \mathrm{Cp},{ }^{26} \mathrm{Na}_{2}^{3} \mathrm{Cp}^{28}$ and $\mathrm{NaCp}^{\mathrm{Ph} 31}$ as well as $\left(\mathrm{C}_{7} \mathrm{H}_{7}\right) \mathrm{Zr}(\mathrm{Cl})(\text { tmeda })^{33}$ were prepared according to literature procedures; a sample of $\mathrm{NaCp}^{\mathrm{BIGC}}$ was kindly provided by Professor S. Harder.

\section{DFT calculations}

For the DFT calculations of the zirconium complexes a B3LYP functional of the Gaussian09, Revision C.01 $01^{34}$ was used. A triple zeta basis $\left(6-311 G^{* *}\right)^{35}$ for the main group elements (C, H) was combined with a double zeta basis (Stuttgart RSC 1997 ECP) ${ }^{36}$ for zirconium, which also includes the effective core potential.

\section{Synthetic work}

HCp $^{\text {cpent }}$ (2-H). To a mechanically stirred mixture of an aqueous $50 \% \mathrm{KOH}$ solution (211 g KOH in $210 \mathrm{~mL}$ water) with the quaternary ammonium salt Adogen $464(3.00 \mathrm{~g})$ and freshly cracked cyclopentadiene (10.0 g, $12.5 \mathrm{~mL}, 151 \mathrm{mmol})$ bromocyclopentane $(47.0 \mathrm{~g}, 3.0 \mathrm{~mL}, 315 \mathrm{mmol})$ was added dropwise via a dropping funnel. The temperature rose to about $55{ }^{\circ} \mathrm{C}$ and the reaction mixture turned brown. After $1 \mathrm{~h}$, more bromocyclopentane $(23.0 \mathrm{~g}, 16.5 \mathrm{~mL}, 154 \mathrm{mmol})$ was added dropwise. The mixture was stirred for $18 \mathrm{~h}$ at $60{ }^{\circ} \mathrm{C}$ and allowed to cool to room temperature. The organic phase was separated and the aqueous phase was extracted twice with petroleum ether (100 mL each). The organic extracts were combined and reduced to an oily residue on a rotary evaporator at $10 \mathrm{mbar}$ and $30{ }^{\circ} \mathrm{C}$. Vacuum distillation of the oily residue at $10^{-2}$ mbar yielded a yellow oil as the main fraction, which consisted of a mixture of tri(cyclopentyl)cyclopentadiene isomers $(30.4 \mathrm{~g}, 113 \mathrm{mmol}, 74 \%)$. GC: $t_{\mathrm{R}}=12.6-13.9 \mathrm{~min}$.

NaCp ${ }^{\text {cpent }}$ (2-Na). Sodium amide $(6.0 \mathrm{~g}, 154 \mathrm{mmol})$ and tri (cyclopentyl)cyclopentadiene isomers (2-H) $(30.0 \mathrm{~g}, 111 \mathrm{mmol})$ were refluxed in THF $(250 \mathrm{~mL})$ for $70 \mathrm{~h}$ under gas evolution. During the reaction, the mixture turned brown and a beige precipitate could be observed. The mixture was filtered hot to remove remaining sodium amide. Volatile components were removed in vacuo and the remaining precipitate was washed with pentane $(200 \mathrm{~mL})$ and dried in vacuo to yield an ivory solid. Yield: $20.5 \mathrm{~g}$ (70.1 mmol, 46\%). GC of a hydrolyzed sample: $t_{\mathrm{R}}=13.2 \mathrm{~min}$.

$\mathbf{H}_{2}^{2} \mathbf{C p}^{\text {TMS }}$ (6-H). $\mathrm{Na}_{2}^{2} \mathrm{Cp}$ (601 mg, $3.0 \mathrm{mmol}$ ) was dissolved in THF (15 mL) and chlorotrimethylsilane $(391 \mu \mathrm{L}, 332 \mathrm{mg}$, $3.06 \mathrm{mmol}$ ) was added slowly at room temperature. The colorless suspension was stirred for $24 \mathrm{~h}$ at room temperature. The pale yellow solution was decanted from insoluble solids and concentrated in vacuo to a yellow oil. Yield: $457 \mathrm{mg}$ (1.82 mmol, 61\%). GC-MS: $t_{\mathrm{R}}=16.1 \mathrm{~min}(\mathrm{~m} / \mathrm{z}=250)$.

$\mathbf{K}_{2}^{2} \mathbf{C p}^{\text {TMS }}$ (6-K). To a solution of $\mathrm{H}_{2}^{2} \mathrm{Cp}^{\text {TMS }}(6-\mathrm{H})$ (752 mg, $3.0 \mathrm{mmol})$ in THF $(15 \mathrm{~mL})$ potassium hydride $(120 \mathrm{mg}$, $3.0 \mathrm{mmol}$ ) was added at room temperature. The reaction mixture was stirred for $3 \mathrm{~d}$ at room temperature resulting in a colourless precipitate. The solvent was removed in a vacuum and the solid was washed with pentane $(2 \times 20 \mathrm{~mL})$ to yield a pale beige potassium salt. Yield: $670 \mathrm{mg}$ (2.32 mmol, 77\%). GC: $t_{\mathrm{R}}=8.0 \mathrm{~min}$.

$\left[\left(\boldsymbol{\eta}^{7}-\mathbf{C}_{7} \mathbf{H}_{7}\right) \mathbf{Z r}\left(\boldsymbol{\eta}^{5}-\mathbf{C p}^{c \text { pent }}\right)\right] \quad$ (2). NaCp ${ }^{c \text { pent }} \quad$ (2-Na) (176 mg, $0.60 \mathrm{mmol})$ was dissolved in THF $(15 \mathrm{~mL})$ and cooled to $-78{ }^{\circ} \mathrm{C}$ in a Schlenk flask. A blue solution of $\left[\left(\eta^{7}-\mathrm{C}_{7} \mathrm{H}_{7}\right) \mathrm{Zr}(\mathrm{Cl})-\right.$ (tmeda)] (1) (200 mg, $0.60 \mathrm{mmol})$ in THF (10 mL) was added slowly with a syringe. After addition, the reaction mixture turned purple and was allowed to warm up to room temperature in $80 \mathrm{~min}$. Stirring was continued for $3 \mathrm{~h}$. The solvent was removed in vacuo and the resulting purple solid was extracted with pentane $(50 \mathrm{~mL})$. An insoluble precipitate was removed by centrifugation. The solution was reduced to a volume of $5 \mathrm{~mL}$ and stored at $-30{ }^{\circ} \mathrm{C}$ for several days. The complex could be obtained as purple needles. Yield: $142 \mathrm{mg}$ (0.32 mmol, 53\%). 
${ }^{1} \mathrm{H}-\mathrm{NMR}\left(600 \mathrm{MHz}, \mathrm{C}_{6} \mathrm{D}_{6}, 298 \mathrm{~K}\right): \delta 5.32(\mathrm{~s}, 2 \mathrm{H}, \mathrm{CpH}), 5.30$ (s, 7H, $\left.\mathrm{C}_{7} \mathrm{H}_{7}\right), 2.68-2.60$ (m, 3H, CH, cpentyl), 1.90-1.49 (m, 24H, $\mathrm{CH}_{2}$, cpentyl). ${ }^{13} \mathrm{C}\left\{{ }^{1} \mathrm{H}\right\}$-NMR (151 MHz, $\left.\mathrm{C}_{6} \mathrm{D}_{6}, 298 \mathrm{~K}\right): \delta 125.4$ (1C, ring C-alkyl), 124.9 (2C, ring C-alkyl), 98.0 (2C, ring $\mathrm{CH}$, $\left.\mathrm{Cp}^{\text {cpent }}\right), 81.4$ (7C, $\left.\mathrm{C}_{7} \mathrm{H}_{7}\right), 40.4$ (1C, $\mathrm{CH}$, alkyl), $38.0\left(2 \mathrm{C}, \mathrm{CH}_{2}\right.$, alkyl), 37.2 (2C, $\mathrm{CH}$, alkyl), 35.0 (2C, $\mathrm{CH}_{2}$, alkyl), 34.2 (2C, $\mathrm{CH}_{2}$, alkyl), 26.1 (2C, $\mathrm{CH}_{2}$, alkyl), 25.9 (2C, $\mathrm{CH}_{2}$, alkyl), 25.6 (2C, $\mathrm{CH}_{2}$, alkyl). Anal. Calcd for $\mathrm{C}_{27} \mathrm{H}_{36} \mathrm{Zr}$ (451.85): C, 71.76; $\mathrm{H}$, 8.05. Found: $\mathrm{C}, 71.24 ; \mathrm{H}, 8.14$.

$\left[\left(\boldsymbol{\eta}^{7}-\mathbf{C}_{7} \mathbf{H}_{7}\right) \operatorname{Zr}\left(\boldsymbol{\eta}^{5}-\mathbf{C p}^{\text {chex }}\right)\right](3) . \mathrm{NaCp}^{\text {chex }}(201 \mathrm{mg}, 0.60 \mathrm{mmol})$ was dissolved in THF (15 mL) and cooled to $-78{ }^{\circ} \mathrm{C}$ in a Schlenk flask. A blue solution of $\left[\left(\eta^{7}-\mathrm{C}_{7} \mathrm{H}_{7}\right) \mathrm{Zr}(\mathrm{Cl})(\right.$ tmeda $\left.)\right](\mathbf{1})$ (200 $\mathrm{mg}, 0.60 \mathrm{mmol})$ in THF $(15 \mathrm{~mL})$ was added slowly with a syringe. After addition, the reaction mixture turned purple and was allowed to warm up to room temperature in 80 minutes. Stirring was continued for 3 hours. The solvent was removed in vacuo, the resulting purple solid was extracted with pentane $(50 \mathrm{~mL})$ and separated from an insoluble precipitate by centrifugation. The solution was concentrated to a volume of $5 \mathrm{~mL}$ and cooled in a refrigerator at $-30{ }^{\circ} \mathrm{C}$ for several days. The complex could be obtained as purple crystals. Yield: $161 \mathrm{mg}$ (0.33 mmol, 54\%). ${ }^{1} \mathrm{H}-\mathrm{NMR}$ (600 MHz, $\mathrm{C}_{6} \mathrm{D}_{6}, 298 \mathrm{~K}$ ): $\delta 5.35(\mathrm{~s}, 2 \mathrm{H}, \mathrm{CpH}), 5.29\left(\mathrm{~s}, 7 \mathrm{H}, \mathrm{C}_{7} \mathrm{H}_{7}\right), 2.34-2.17(\mathrm{~m}, 3 \mathrm{H}, \mathrm{CH}$, chexyl), 1.94-1.04 (m, 30H, $\mathrm{CH}_{2}, \quad$ chexyl). ${ }^{13} \mathrm{C}\left\{{ }^{1} \mathrm{H}\right\}-\mathrm{NMR}$ (151 MHz, $\left.\mathrm{C}_{6} \mathrm{D}_{6}, 298 \mathrm{~K}\right): \delta 129.2$ (1C, ring C-alkyl), 126.9 (2C, ring C-alkyl), 97.4 (2C, ring $\left.\mathrm{CH}, \mathrm{Cp}^{\text {chex }}\right), 81.5\left(\mathrm{C}_{7} \mathrm{H}_{7}\right), 38.7$ (1C, $\mathrm{CH}$, alkyl), 37.5 (2C, $\mathrm{CH}$, alkyl), 36.7 (2C, $\mathrm{CH}_{2}$, alkyl $\left.\mathrm{C} \beta\right), 35.2$ (2C, $\mathrm{CH}_{2}$, alkyl $\mathrm{C} \beta$ ), 35.1 (2C, $\mathrm{CH}_{2}$, alkyl $\left.\mathrm{C} \beta\right), 27.34\left(2 \mathrm{C}, \mathrm{CH}_{2}\right.$, alkyl $\mathrm{C} \gamma$ ), 27.30 (2C, $\mathrm{CH}_{2}$, alkyl $\left.\mathrm{C} \gamma\right), 27.0\left(2 \mathrm{C}, \mathrm{CH}_{2}\right.$, alkyl $\left.\mathrm{C} \gamma\right)$,

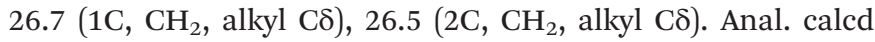
for $\mathrm{C}_{30} \mathrm{H}_{42} \mathrm{Zr}$ (493.94): C, 72.94; $\mathrm{H}$, 8.59. Found: C, 71.67; $\mathrm{H}, 8.74$.

$\left[\left(\boldsymbol{\eta}^{7}-\mathbf{C}_{7} \mathbf{H}_{7}\right) \mathbf{Z r}\left(\boldsymbol{\eta}^{5}{ }^{3} \mathbf{C p}\right)\right](\mathbf{4}) . \mathrm{Na}^{3} \mathrm{Cp}(129 \mathrm{mg}, 0.60 \mathrm{mmol})$ was dissolved in THF $(15 \mathrm{~mL})$ and cooled to $-78{ }^{\circ} \mathrm{C}$ in a Schlenk flask. A blue solution of $\left[\left(\eta^{7}-\mathrm{C}_{7} \mathrm{H}_{7}\right) \mathrm{Zr}(\mathrm{Cl})(\right.$ tmeda $\left.)\right]$ (1) $(200 \mathrm{mg}$, $0.60 \mathrm{mmol})$ in THF $(15 \mathrm{~mL})$ was added slowly with a syringe. The reaction mixture turned dark brownish-red and was allowed to warm up to room temperature in 80 minutes. Stirring was continued for 3 hours at room temperature. The solvent was removed in vacuo and the resulting purple solid was extracted with pentane $(50 \mathrm{~mL})$ and separated from an insoluble precipitate by centrifugation. The solution was reduced to $1 / 10$ of the volume and stored in a refrigerator at $-30{ }^{\circ} \mathrm{C}$ for several days, where the complex formed purple crystals. Yield: $135 \mathrm{mg}$ (0.36 mmol, 60\%). ${ }^{1} \mathrm{H}-\mathrm{NMR}(400 \mathrm{MHz}$, $\left.\mathrm{C}_{6} \mathrm{D}_{6}, 298 \mathrm{~K}\right): \delta 5.33(\mathrm{~s}, 2 \mathrm{H}, \mathrm{CpH}), 5.26\left(\mathrm{~s}, 7 \mathrm{H}, \mathrm{C}_{7} \mathrm{H}_{7}\right), 2.57$ (sept, $1 \mathrm{H}, \mathrm{CH}$, isopropyl), 2.49 (sept, $2 \mathrm{H}, \mathrm{CH}$, isopropyl), 1.17 (d, $6 \mathrm{H}$, ${ }^{3} J=6.9 \mathrm{~Hz}, \mathrm{CH}_{3}$, isopropyl), 1.07 (d, $6 \mathrm{H},{ }^{3} \mathrm{~J}=6.9 \mathrm{~Hz}, \mathrm{CH}_{3}$, isopropyl), 0.98 (d, 6H, ${ }^{3} J=6.8 \mathrm{~Hz}, \mathrm{CH}_{3}$, isopropyl). ${ }^{13} \mathrm{C}\left\{{ }^{1} \mathrm{H}\right\}-\mathrm{NMR}$ (151 MHz, $\left.\mathrm{C}_{6} \mathrm{D}_{6}, 298 \mathrm{~K}\right): \delta 128.4\left(\mathrm{C}_{\mathrm{q}},{ }^{3} \mathrm{Cp}\right), 127.5\left(\mathrm{C}_{\mathrm{q}},{ }^{3} \mathrm{Cp}\right), 96.9$ $\left(\mathrm{CH},{ }^{3} \mathrm{Cp}\right), 81.5\left(\mathrm{C}_{7} \mathrm{H}_{7}\right), 28.6\left(\mathrm{CH}\right.$, isopropyl), $24.6\left(\mathrm{CH}_{3}\right.$, isopropyl), $24.1\left(\mathrm{CH}_{3}\right.$, isopropyl). Anal. calcd for $\mathrm{C}_{21} \mathrm{H}_{30} \mathrm{Zr}$ (373.73): C, 67.48; H, 8.11. Found: C, 66.97; H, 8.02.

$\left[\left(\boldsymbol{\eta}^{7}-\mathbf{C}_{7} \mathbf{H}_{7}\right) \mathbf{Z r}\left(\boldsymbol{\eta}^{5}{ }_{2}^{2} \mathbf{C p}\right)\right](5) . \mathrm{Na}_{2}^{2} \mathrm{Cp}(120 \mathrm{mg}, 0.60 \mathrm{mmol})$ was suspended in THF (15 mL) and cooled to $-78{ }^{\circ} \mathrm{C}$ in a Schlenk flask. A blue solution of $\left[\left(\eta^{7}-\mathrm{C}_{7} \mathrm{H}_{7}\right) \mathrm{Zr}(\mathrm{Cl})(\right.$ tmeda) $\left.)\right]$ (1) (200 mg,
$0.60 \mathrm{mmol})$ in THF $(15 \mathrm{~mL})$ was added slowly with a syringe. After addition, the reaction mixture turned purple immediately and was allowed to warm up to room temperature, which took $30 \mathrm{~min}$. Stirring was continued for $1 \mathrm{~h}$ at room temperature. The solvent was removed in a vacuum and the resulting purple solid was extracted with pentane $(50 \mathrm{~mL})$. An insoluble precipitate was removed by centrifugation. Solvent removal in vacuo yielded a purple solid. Analytically pure samples could be obtained by crystallization from a concentrated pentane solution at $-30{ }^{\circ} \mathrm{C}$ or sublimation in a sealed glass tube at $10^{-3}$ mbar at $120{ }^{\circ} \mathrm{C}$. Yield: $163 \mathrm{mg}(0.45 \mathrm{mmol}, 76 \%) .{ }^{1} \mathrm{H}-\mathrm{NMR}$ (400 MHz, $\left.\mathrm{C}_{6} \mathrm{D}_{6}, 298 \mathrm{~K}\right): \delta 5.22\left(\mathrm{~s}, 7 \mathrm{H}, \mathrm{C}_{7} \mathrm{H}_{7}\right), 5.14(\mathrm{~s}, 1 \mathrm{H}, \mathrm{CpH})$, 2.66 (sept, $2 \mathrm{H},{ }^{3} J=7.2 \mathrm{~Hz}, \mathrm{CH}$, isopropyl), 1.89 (s, 6H, $\mathrm{CpCH}_{3}$ ), $1.20\left(\mathrm{~d}, 6 \mathrm{H},{ }^{3} \mathrm{~J}=7.2 \mathrm{~Hz}, \mathrm{CH}_{3}\right.$, isopropyl), $1.08\left(\mathrm{~d}, 6 \mathrm{H},{ }^{3} \mathrm{~J}=\right.$ $7.1 \mathrm{~Hz}, \mathrm{CH}_{3}$, isopropyl). ${ }^{13} \mathrm{C}\left\{{ }^{1} \mathrm{H}\right\}-\mathrm{NMR}\left(151 \mathrm{MHz}, \mathrm{C}_{6} \mathrm{D}_{6}, 298 \mathrm{~K}\right)$ : $\delta 126.1$ ( $\mathrm{C}_{\mathrm{q}}, \mathrm{C} 1 \mathrm{p}$-isopropyl), $112.0\left(\mathrm{C}_{\mathrm{q}}, \mathrm{Cp}\right.$-methyl), $106.0(\mathrm{CH}$, $\left.{ }_{2}^{2} \mathrm{Cp}\right), 81.9\left(\mathrm{C}_{7} \mathrm{H}_{7}\right), 26.5$ ( $\mathrm{CH}$, isopropyl), $24.2\left(\mathrm{CH}_{3}\right.$, isopropyl), $24.1\left(\mathrm{CH}_{3}\right.$, isopropyl), $14.6\left(\mathrm{CH}_{3}\right)$. Anal. Calcd for $\mathrm{C}_{20} \mathrm{H}_{28} \mathrm{Zr}$ (359.70): C, 66.78; H, 7.86. Found: C, 65.93; H, 7.71.

$\left[\left(\boldsymbol{\eta}^{7}-\mathbf{C}_{7} \mathbf{H}_{7}\right) \operatorname{Zr}\left(\boldsymbol{\eta}^{5}-2{ }_{2}^{2} \mathbf{C} \mathbf{p}^{\text {TMS }}\right)\right] \quad$ (6). $\mathrm{K}_{2}^{2} \mathrm{Cp}^{\mathrm{TMS}} \quad(6-\mathrm{K}) \quad(173 \quad \mathrm{mg}$, $0.60 \mathrm{mmol})$ was suspended in THF $(15 \mathrm{~mL})$ and cooled to $-78{ }^{\circ} \mathrm{C}$ in a Schlenk flask. A blue solution of $\left[\left(\eta^{7}-\mathrm{C}_{7} \mathrm{H}_{7}\right) \mathrm{Zr}(\mathrm{Cl})-\right.$ (tmeda)] (1) (200 mg, $0.60 \mathrm{mmol})$ in THF (15 mL) was added slowly with a syringe. After addition, the reaction mixture turned pink and was warmed-up to rt in 80 minutes meanwhile the colour changed from pink via brown to dark red. Stirring was continued for 3 hours at room temperature. The solvent of the purple solution was removed in a vacuum and the resulting purple solid was extracted with pentane $(50 \mathrm{~mL})$ and an insoluble precipitate was removed by centrifugation. The solution was concentrated to a volume of $5 \mathrm{~mL}$ and cooled in a fridge at $-30{ }^{\circ} \mathrm{C}$ for several days. The complex could be obtained as purple crystals. Yield: $100 \mathrm{mg}$ (0.23 mmol, 39\%). ${ }^{1} \mathrm{H}-\mathrm{NMR}\left(400 \mathrm{MHz}, \mathrm{C}_{6} \mathrm{D}_{6}, 298 \mathrm{~K}\right): \delta 5.25\left(\mathrm{~s}, 7 \mathrm{H}, \mathrm{C}_{7} \mathrm{H}_{7}\right), 2.77$ (sept, br, 2H, CH, isopropyl), $2.05\left(\mathrm{~s}, 6 \mathrm{H}, \mathrm{CH}_{3}\right), 1.22(\mathrm{~d}, 6 \mathrm{H}$, ${ }^{3} J=7.3 \mathrm{~Hz}, \mathrm{CH}_{3}$, isopropyl), $1.13\left(\mathrm{~d}, 6 \mathrm{H},{ }^{3} \mathrm{~J}=7.2 \mathrm{~Hz}, \mathrm{CH}_{3}\right.$, isopropyl), 0.32 (s, 9H, $\left.\mathrm{Si}\left(\mathrm{CH}_{3}\right)_{3}\right) .{ }^{13} \mathrm{C}\left\{{ }^{1} \mathrm{H}\right\}-\mathrm{NMR}$ (151, $\mathrm{C}_{6} \mathrm{D}_{6}$, $298 \mathrm{~K}): \delta 129.9\left(\mathrm{C}_{\mathrm{q}},{ }_{2}^{2} \mathrm{Cp}^{\mathrm{TMS}}\right), 128.3\left(\mathrm{C}_{\mathrm{q}},{ }_{2}^{2} \mathrm{Cp}^{\mathrm{TMS}}\right), 119.8\left(\mathrm{C}_{\mathrm{q}}\right.$, Cp-Si), $82.1\left(\mathrm{C}_{7} \mathrm{H}_{7}\right), 26.4$ ( $\mathrm{CH}$, isopropyl), $24.3\left(\mathrm{CH}_{3}\right.$, isopropyl), $24.0\left(\mathrm{CH}_{3}\right.$, isopropyl), $15.3\left(\mathrm{CH}_{3}\right), 3.1\left(\mathrm{Si}\left(\mathrm{CH}_{3}\right)_{3}\right) .{ }^{29} \mathrm{Si}-\mathrm{NMR}$ (119 MHz, $\mathrm{C}_{6} \mathrm{D}_{6} /$ tetramethylsilane, $\left.298 \mathrm{~K}\right): \delta-9.27\left(\mathrm{Si}\left(\mathrm{CH}_{3}\right)_{3}\right)$. Anal. Calcd for $\mathrm{C}_{23} \mathrm{H}_{36} \mathrm{SiZr}$ (431.90): C, 63.96; H, 8.42. Found: $\mathrm{C}, 63.87 ; \mathrm{H}, 8.44$.

$\left[\left(\boldsymbol{\eta}^{7}-\mathbf{C}_{7} \mathbf{H}_{7}\right) \mathbf{Z r}\left(\boldsymbol{\eta}^{5}{ }_{2}^{3} \mathbf{C p}\right)\right](7) . \mathrm{Na}_{2}^{3} \mathrm{Cp}(145 \mathrm{mg}, 0.60 \mathrm{mmol})$ was suspended in THF $(10 \mathrm{~mL})$ and cooled to $-78{ }^{\circ} \mathrm{C}$ in a Schlenk flask. A blue solution of $\left[\left(\eta^{7}-\mathrm{C}_{7} \mathrm{H}_{7}\right) \mathrm{Zr}(\mathrm{Cl})(\right.$ tmeda) $]$ (1) $(200 \mathrm{mg}$, $0.60 \mathrm{mmol})$ in THF $(10 \mathrm{~mL})$ was added slowly with a syringe. The reaction mixture changed colour from grey to green and was allowed to warm up to room temperature in 80 minutes. Stirring was continued for 3 hours at room temperature. The purple solution was evaporated to dryness and the pentane extract $(50 \mathrm{~mL})$ of the purple residue was separated from an insoluble precipitate by centrifugation. The solvent was removed in vacuo yielding a purple oil, which could not be crystallized. Yield: $108 \mathrm{mg}(0.27 \mathrm{mmol}, 45 \%) .{ }^{1} \mathrm{H}-\mathrm{NMR}$ $\left(400 \mathrm{MHz}, \mathrm{C}_{6} \mathrm{D}_{6}, 298 \mathrm{~K}\right): \delta 5.23$ (s. $\left.7 \mathrm{H}, \mathrm{C}_{7} \mathrm{H}_{7}\right), 2.78-2.73(\mathrm{~m}, 3 \mathrm{H}$, 
$\mathrm{CH}$, isopropyl), 1.96 (s, 6H, $\mathrm{CH}_{3}$, methyl), 1.24 (d, 6H, ${ }^{3} \mathrm{~J}=$ $7.2 \mathrm{~Hz}, \mathrm{CH}_{3}$, isopropyl), 1.18 (d, $6 \mathrm{H},{ }^{3} \mathrm{~J}=7.1 \mathrm{~Hz}, \mathrm{CH}_{3}$, isopropyl), $1.14\left(\mathrm{~d}, 6 \mathrm{H},{ }^{3} \mathrm{~J}=7.2 \mathrm{~Hz}, \mathrm{CH}_{3}\right.$, isopropyl). ${ }^{13} \mathrm{C}\left\{{ }^{1} \mathrm{H}\right\}-\mathrm{NMR}$ (151 MHz, $\left.\mathrm{C}_{6} \mathrm{D}_{6}, 298 \mathrm{~K}\right): \delta 126.5\left(\mathrm{C}_{\mathrm{q}},{ }_{2}^{3} \mathrm{Cp}\right), 125.5\left(\mathrm{C}_{\mathrm{q}},{ }_{2}^{3} \mathrm{Cp}\right)$, $111.7\left(\mathrm{C}_{\mathrm{q}},{ }_{2}^{3} \mathrm{Cp}\right), 82.1\left(\mathrm{C}_{7} \mathrm{H}_{7}\right), 27.7(\mathrm{CH}$, isopropyl), $26.4(\mathrm{CH}$, isopropyl), $24.6\left(\mathrm{CH}_{3}\right.$, isopropyl), 24.2 ( $\mathrm{CH}$, isopropyl), 24.1 $\left(\mathrm{CH}_{3}\right.$, isopropyl), $12.5\left(\mathrm{CH}_{3}\right.$, methyl). Anal. calcd for $\mathrm{C}_{23} \mathrm{H}_{34} \mathrm{Zr}$ (401.79): C, 68.75; H, 8.55. Found: C, 68.54; H, 8.43.

$\left[\left(\boldsymbol{\eta}^{7}-\mathbf{C}_{7} \mathbf{H}_{7}\right) \mathbf{Z r}\left(\boldsymbol{\eta}^{5}-\mathbf{C} \mathbf{p}^{\mathbf{P h}}\right)\right](\mathbf{8})$. To a solution of $\left[\left(\eta^{7}-\mathrm{C}_{7} \mathrm{H}_{7}\right) \mathrm{Zr}(\mathrm{Cl})-\right.$ (tmeda)] (1) (206 mg, $0.62 \mathrm{mmol}$ ) in THF (20 mL) cooled to $-78{ }^{\circ} \mathrm{C}$ a solution of $\mathrm{NaCp}^{\mathrm{Ph}}(303 \mathrm{mg}, 0.65 \mathrm{mmol})$ in THF $(15 \mathrm{~mL})$ was added dropwise over a period of $10 \mathrm{~min}$. The mixture was allowed to thaw to room temperature. Stirring was continued for $2 \mathrm{~h}$, while the colour of the solution turned purple. After removal of solids by filtration the solvent was evaporated and the residue was washed twice with small amounts of THF. Drying in vacuo afforded $179 \mathrm{mg}(0.29 \mathrm{mmol}$, $46 \%$ ) of a purple solid. ${ }^{1} \mathrm{H}-\mathrm{NMR}$ (300 MHz, THF-d8, $297 \mathrm{~K}$ ): $\delta$ 7.26-6.97 (m, 25H, Ph), $5.41\left(\mathrm{~s}, 7 \mathrm{H}, \mathrm{C}_{7} \mathrm{H}_{7}\right) .{ }^{13} \mathrm{C}\left\{{ }^{1} \mathrm{H}\right\}-\mathrm{NMR}$ (151 MHz, THF-d8, $297 \mathrm{~K}): \delta 135.5$ (ipso- $\mathrm{C}_{6} \mathrm{H}_{5}$ ), $133.1\left(\mathrm{~m} / \mathrm{o}^{-}\right.$ $\left.\mathrm{C}_{5} \mathrm{Ph}_{5}\right), 128.2\left(\mathrm{o} / m-\mathrm{C}_{6} \mathrm{H}_{5}\right), 127.3\left(p-\mathrm{C}_{6} \mathrm{H}_{5}\right), 122.9(\mathrm{Cp}), 86.3$ $\left(\mathrm{C}_{7} \mathrm{H}_{7}\right)$. MS (EI, $\left.70 \mathrm{eV}\right): \mathrm{m} / \mathrm{z} 626.1\left(\mathrm{M}^{+}, 100\right)$. HR-MS (EI, $\left.\mathrm{m} / \mathrm{z}\right)$ : calcd for $\mathrm{C}_{42} \mathrm{H}_{32} \mathrm{Zr}\left(\mathrm{M}^{+}\right)$626.15456, found 626.15364.

$\left[\left(\boldsymbol{\eta}^{7}-\mathbf{C}_{7} \mathbf{H}_{7}\right) \mathbf{Z r}\left(\boldsymbol{\eta}^{5}-\mathbf{C} \mathbf{p}^{\text {BIGc }}\right)\right]$ (9). To a suspension of $\mathrm{KCp}^{\mathrm{BIG} c}$ $(324 \mathrm{mg}, 0.60 \mathrm{mmol})$ in THF $(15 \mathrm{~mL})$ a blue solution of $\left[\left(\eta^{7}-\right.\right.$ $\left.\left.\mathrm{C}_{7} \mathrm{H}_{7}\right) \mathrm{Zr}(\mathrm{Cl})(\mathrm{tmeda})\right]$ (1) (200 mg, $\left.0.60 \mathrm{mmol}\right)$ in THF $(15 \mathrm{~mL})$ was added with a syringe at room temperature. The reaction mixture was stirred for $3 \mathrm{~d}$ and turned slowly brownish-yellow. The solvent was removed in vacuo and the resulting brown solid was washed with pentane $(50 \mathrm{~mL})$. The remaining mixture of solids was extracted with toluene $(50 \mathrm{~mL})$ and separated from an insoluble material by centrifugation. Evaporation of the solution to dryness afforded a purple solid (142 mg, $0.21 \mathrm{mmol}, 35 \%) .{ }^{1} \mathrm{H}-\mathrm{NMR}$ (400 MHz, $\mathrm{C}_{6} \mathrm{D}_{6}, 298 \mathrm{~K}$ ): $\delta$ 7.23-7.13 (m, 8H, CH, phenyl), 6.95-6.90 (m, 12H, $\mathrm{CH}$, phenyl), $6.79\left(\mathrm{~d}, 4 \mathrm{H},{ }^{3} \mathrm{~J}=8.2 \mathrm{~Hz}, \mathrm{CH}\right.$, phenyl), $5.48(\mathrm{~s}, 7 \mathrm{H}$, $\mathrm{C}_{7} \mathrm{H}_{7}$ ), 1.43-1.11 (m, 9H, n-butyl). ${ }^{13} \mathrm{C}\left\{{ }^{1} \mathrm{H}\right\}$-NMR (150 MHz, $\left.\mathrm{C}_{6} \mathrm{D}_{6}, 298 \mathrm{~K}\right): \delta 134.9\left(\mathrm{C}_{6} \mathrm{H}_{5}\right), 134.8\left(\mathrm{C}_{6} \mathrm{H}_{5}\right), 132.6\left(\mathrm{C}_{6} \mathrm{H}_{5}\right), 132.6$ $\left(\mathrm{C}_{6} \mathrm{H}_{5}\right), 126.8\left(\mathrm{C}_{6} \mathrm{H}_{5}\right), 122.2\left(\mathrm{C}_{\mathrm{q}}, \mathrm{Cp}^{\mathrm{BIGc}}\right), 85.9\left(\mathrm{C}_{7} \mathrm{H}_{7}\right), 35.6\left(\mathrm{CH}_{2}\right.$, $n$-butyl), $33.5\left(\mathrm{CH}_{2}, n\right.$-butyl $), 22.7\left(\mathrm{CH}_{2}, n\right.$-butyl $), 14.3\left(\mathrm{CH}_{3}\right.$, $n$-butyl). Anal. calcd for $\mathrm{C}_{46} \mathrm{H}_{40} \mathrm{Zr}$ (684.08): C, 80.76; H, 5.91. Found: C, 79.24; H, 5.03.

$\left[\left(\boldsymbol{\eta}^{7}-\mathbf{C}_{7} \mathbf{H}_{7}\right) \mathbf{Z r}\left(\boldsymbol{\eta}^{5}\right.\right.$-Ind $\left.\left.\mathbf{I}^{\prime}\right)\right](\mathbf{1 0})$. NaInd' (150 mg, $\left.0.70 \mathrm{mmol}\right)$ was suspended in THF $(10 \mathrm{~mL})$ and cooled to $-78^{\circ} \mathrm{C}$ in a Schlenk flask. A blue solution of $\left[\left(\eta^{7}-\mathrm{C}_{7} \mathrm{H}_{7}\right) \mathrm{Zr}(\mathrm{Cl})(\mathrm{tmeda})\right]$ (1) $(234 \mathrm{mg}$, $0.70 \mathrm{mmol})$ in THF $(15 \mathrm{~mL})$ was added slowly with a syringe. The reaction mixture was allowed to thaw to room temperature, which took ca. 80 minutes. During this period the colour of the reaction mixture changed from grey to purple-red. Stirring was continued for $5 \mathrm{~h}$ at room temperature. The solvent was removed in vacuo and the resulting purple solid was extracted with pentane $(50 \mathrm{~mL})$. After removal of insoluble side products by centrifugation the solution was concentrated to a volume of $5 \mathrm{~mL}$ and stored at $-30{ }^{\circ} \mathrm{C}$ for several days to afford purple needles (177 mg, $0.33 \mathrm{mmol}, 47 \%$ ). ${ }^{1} \mathrm{H}-\mathrm{NMR}$ (400 MHz, $\left.\mathrm{C}_{6} \mathrm{D}_{6}, 298 \mathrm{~K}\right): \delta 7.51-7.48$ (m, 1H, Ind'), 7.26-7.23 (m, 1H, Ind'), 6.78-6.74 (m, 2H, H5, H6, Ind'), 5.70 (dd, 1H, ${ }^{3} J=3.7 \mathrm{~Hz},{ }^{4} J=0.8 \mathrm{~Hz}, \mathrm{H} 3$, Ind $\left.^{\prime}\right), 5.50$ (d, $1 \mathrm{H},{ }^{3} J=3.7 \mathrm{~Hz}, \mathrm{H} 2$, Ind'), 5.01 (s, 7H, $\mathrm{C}_{7} \mathrm{H}_{7}$ ), 1.25 (s, 9H, $\mathrm{CH}_{3}$, tert-butyl). ${ }^{13} \mathrm{C}\left\{{ }^{1} \mathrm{H}\right\}-$ NMR (151 MHz, $\left.\mathrm{C}_{6} \mathrm{D}_{6}, 298 \mathrm{~K}\right): \delta 124.0\left(\mathrm{CH}\right.$, Ind' $\left.^{\prime}\right), 123.0\left(\mathrm{C}_{\mathrm{q}}\right.$, Ind'), 122.8 ( $\mathrm{CH}$, Ind $\left.^{\prime}\right), 122.4$ ( $\mathrm{C}_{\mathrm{q}}$, Ind'), 122.1 ( $\mathrm{CH}$, Ind' $\left.^{\prime}\right), 121.8$ (CH, Ind'), 119.2 ( $\mathrm{C}_{\mathrm{q}}$, Ind'), 105.6 (C3, Ind'), 90.2 (C2, Ind'), $83.4\left(\mathrm{C}_{7} \mathrm{H}_{7}\right), 32.9\left(\mathrm{C}_{\mathrm{q}}\right.$, tert-butyl $), 32.0\left(\mathrm{CH}_{3}\right.$, tert-butyl $)$. Anal. Calcd for $\mathrm{C}_{20} \mathrm{H}_{22} \mathrm{Zr}$ (353.64): C, 67.92; H, 6.28. Found: C, 67.13; H, 6.26.

\section{Acknowledgements}

H. S. is grateful to Professor Scherer for many years of friendly support. The authors thank Professor S. Harder for providing a sample of the sodium salt $\mathrm{NaCp}^{\mathrm{BIG} c}$.

\section{Notes and references}

1 S. A. Miller, J. A. Tebboth and J. F. Tremaine, J. Chem. Soc., 1952, 632-635.

2 P. Laszlo and R. Hoffmann, Angew. Chem., 2000, 112, 127128, (Angew. Chem., Int. Ed., 2000, 39, 123-124).

3 G. Wilkinson, J. Organomet. Chem., 1975, 100, 273-278.

4 E. O. Fischer and W. Pfab, Z. Naturforsch., B: Anorg. Chem. Org. Chem. Biochem. Biophys. Biol., 1952, 7, 377-379.

5 H. Röhl, E. Lange, T. Gößl and G. Roth, Angew. Chem., Int. Ed. Engl., 1962, 74, 155.

6 R. B. King and A. Efraty, J. Am. Chem. Soc., 1972, 94, 37733779.

7 C. Janiak and H. Schumann, Adv. Organomet. Chem., 1991, 33, 291-393.

8 J. Okuda, Top. Curr. Chem., 1991, 160, 97-145.

9 W. Kaminsky, Rapra Rev. Rep., 2000, 10, 1-136.

10 C. A. Tolman, J. Am. Chem. Soc., 1970, 92, 2956-2965.

11 Literature search was carried out in August 2013, only compounds with experimental properties have been counted.

12 C. A. Tolman, Chem. Rev., 1977, 77, 313-348. This article received more than 3700 citations, is still earning more than one hundred citations per year and has been referred to in many textbooks on inorganic chemistry.

13 P. C. Möhring and N. J. Coville, J. Organomet. Chem., 1994, 479, 1-29.

14 P. C. Möhring and N. J. Coville, J. Mol. Catal., 1992, 77, 41-50.

15 P. C. Möhring and N. J. Coville, J. Mol. Catal., 1995, 96, 181-195.

16 P. C. Möhring, M. Vlachakis, N. E. Grimmer and N. J. Coville, J. Organomet. Chem., 1994, 483, 159-166.

17 C. Janiak, U. Versteeg, K. C. H. Lange, R. Weimann and E. Hahn, J. Organomet. Chem., 1995, 501, 219-234.

18 C. Janiak, K. C. H. Lange, U. Versteeg, D. Lentz and P. H. M. Budzelaar, Chem. Ber., 1996, 129, 1517-1529. 
19 D. White and N. J. Coville, Adv. Organomet. Chem., 1994, 36, 95-158.

20 P. C. Möhring and N. J. Coville, Coord. Chem. Rev., 2006, 250, 18-35.

21 N. J. Coville, M. S. Loonat, D. White and L. Carlton, Organometallics, 1992, 11, 1082-1090.

22 A. Glöckner, H. Bauer, M. Maekawa, T. Bannenberg, C. G. Daniliuc, P. G. Jones, Y. Sun, H. Sitzmann, M. Tamm and M. Walter, Dalton Trans., 2012, 41, 66146624.

23 A. Glöckner and M. Tamm, Chem. Soc. Rev., 2013, 42, 128142.

24 D. Weismann, D. Saurenz, R. Boese, D. Bläser, G. Wolmershäuser, Y. Sun and H. Sitzmann, Organometallics, 2011, 30, 6351-6364.

25 C. G. Venier and E. W. Casserly, J. Am. Chem. Soc., 1990, 112, 2808-2809.

26 S. Schäfer, H. Bauer, J. Becker, Y. Sun and H. Sitzmann, Eur. J. Inorg. Chem., 2013, 5694-5700.

27 H. Sitzmann, J. Organomet. Chem., 1988, 354, 203-214.

28 V. Quindt, D. Saurenz, O. Schmitt, M. Schär, T. Dezember, G. Wolmershäuser and H. Sitzmann, J. Organomet. Chem., 1999, 579, 376-384.

29 L. D. Field, T. W. Hambley, C. M. Lindall and A. F. Masters, Inorg. Chem., 1992, 31, 2366-2370.

30 H. Schumann, C. Janiak and H. Khani, J. Organomet. Chem., 1987, 330, 347-355.

31 R. Zhang, M. Tsutsui and D. E. Bergbreiter, J. Organomet. Chem., 1982, 229, 109-112.
32 J. A. Burman, M. L. Hays, D. J. Burkey, P. S. Tanner and T. P. Hanusa, J. Organomet. Chem., 1994, 479, 135139.

33 A. Glöckner, T. Bannenberg, M. Tamm, A. M. Arif and R. D. Ernst, Organometallics, 2009, 28, 5866-5876.

34 M. J. Frisch, G. W. Trucks, H. B. Schlegel, G. E. Scuseria, M. A. Robb, J. R. Cheeseman, G. Scalmani, V. Barone, B. Menucci, G. A. Petersson, H. Nakatsuji, M. Caricato, X. Li, H. P. Hratchian, A. F. Izmaylow, J. Bloino, G. Zheng, J. L. Sonnenberg, M. Hada, M. Ehara, K. Toyota, R. Fukuda, J. Hasegawa, M. Ishida, T. Nakajima, Y. Honda, O. Kitao, H. Nakai, T. Vreven, J. A. Montgomery, Jr., J. E. Peralta, F. Ogliaro, M. Bearpark, J. J. Heyd, E. Brothers, K. N. Kudin, V. N. Staroverov, T. Keith, R. Kobayashi, J. Normand, K. Raghavachari, A. Rendell, J. C. Burant, S. S. Iyengar, J. Tomasi, M. Cossi, N. Rega, J. M. Millam, M. Klene, J. E. Knox, J. B. Cross, V. Bakken, C. Adamo, J. Jaramillo, R. Gomperts, R. E. Stratmann, O. Yazyev, A. J. Austin, R. Cammi, C. Pomelli, J. W. Ochterski, R. L. Martin, K. Morokuma, V. G. Zakrzewski, G. A. Voth, P. Salvador, J. J. Dannenberg, S. Dapprich, A. D. Daniels, O. Farkas, J. B. Foresman, J. V. Ortiz, J. Cioslowski and D. J. Fox, Gaussian09 (Revision C.01), Gaussian, Inc., Wallingford, CT, 2010.

35 X. Cao and M. Dolg, J. Chem. Phys., 2001, 115, 7348-7355.

36 (a) A. Bergner, M. Dolg, W. Kuechle, H. Stoll and H. Preuss, Mol. Phys., 1993, 80, 1431-1441; (b) M. Kaupp, P. v. R. Schleyer, H. Stoll, H. Preuss and R. M. Pitzer, J. Phys. Chem., 1993, 97, 5852-5859. 